\title{
Recent advances in the use of opioids for cancer pain
}

\author{
This article was published in the following Dove Press journal: \\ Journal of Pain Research \\ 22 September 2009 \\ Number of times this article has been viewed
}

\section{Joanne Droney Julia Riley}

Palliative Medicine Department, Royal Marsden Hospital, London, UK

Correspondence: Joanne Droney Palliative Medicine Department, Royal Marsden Hospital, London, UK Tel +4420780 8276I Email jodroney@hotmail.com
Abstract: Opioids are the mainstay of treatment for moderate to severe cancer pain. In recent years there have been many advances in the use of opioids for cancer pain. Availability and consumption of opioids have increased and opioids other than morphine (including methadone, fentanyl, oxycodone) have become more widely used. Inter-individual variation in response to opioids has been identified as a significant challenge in the management of cancer pain. Many studies have been published demonstrating the benefits of opioid switching as a clinical maneuver to improve tolerability. Constipation has been recognized as a significant burden in cancer patients on opioids. Peripherally restricted opioid antagonists have been developed for the prevention and management of opioid induced constipation. The phenomenon of breakthrough pain has been characterized and novel modes of opioid administration (transmucosal, intranasal, sublingual) have been explored to facilitate improved management of breakthrough cancer pain. Advances have also been made in the realm of molecular biology. Pharmacogenetic studies have explored associations between clinical response to opioids and genetic variation at a DNA level. To date these studies have been small but future research may facilitate prospective prediction of response to individual drugs.

Keywords: opioids, cancer, pain, pharmacogenetics, constipation, breakthrough pain

\section{Introduction}

Most patients with cancer experience pain at some stage in their illness and many of these require opioid analgesia. For the past 20 years cancer pain has been managed according to the World Health Organization (WHO) analgesic ladder. This three-step ladder recommends sequential increases in the strength of analgesia, starting with paracetamol (step 1), adding in a weak opioid (step 2) if the pain persists and finally progressing to a strong opioid (step 3) if pain is still not controlled. ${ }^{1}$ The use of the analgesic ladder has been validated in numerous studies and can result in over $80 \%$ analgesic control. . $^{23}$

There have been a number of developments in the use of opioids for cancer pain in recent years including:

- Choice and availability of opioids

- The use of alternative opioids to morphine and opioid switching

- Advances in the methods of delivery of opioids for cancer pain

- Advances in the methods of managing opioid-induced side-effects, particularly with the advent of opioid antagonists

- An increased knowledge and awareness of the molecular basis for opioid effect including pharmacogenetics 
Much of the research on opioids has initially been carried out in a non-malignant setting, often involving experimental pain studies. Some of these data however can be extrapolated to a certain degree to cancer patients. Most of these studies influence the direction of research in the use of opioids for cancer pain. All of these advances have improved individualized pain management and pave the way for the future of pain medicine ie personalized prescribing.

\section{Recent advances in the use of opioids for cancer pain: opioid availability and choice}

Morphine is the WHO first line strong opioid of choice for cancer pain. ${ }^{1,4}$ This recommendation is based on availability and cost rather then evidence of superior efficacy or tolerability. Despite this recommendation, however, until relatively recently morphine was unavailable or not commonly used in many countries. In 1991 twenty countries accounted for $86 \%$ of morphine consumption. ${ }^{5}$ In 2006 Europe and North America accounted for 89\% of global morphine consumption with developing countries, which account for $80 \%$ of the world's population only consuming $6 \%$ of worldwide morphine. ${ }^{6}$ Reasons for this inequality in morphine use/availability include:

- Inadequate health care infrastructures or pain control as a low priority item in a country's national health agenda

- Lack of knowledge/skills in pain treatment. Even in the US, in a survey of 897 physicians, reluctance to prescribe opioids for cancer pain was cited by $61 \%$ of respondents. $^{7}$

- Legal and regulatory issues surrounding the use and availability of opioids. ${ }^{8}$

- Fear of addiction and misuse or re-direction of opioids into the illegal drug trade. ${ }^{9}$

In 1984 the WHO Cancer Pain Relief Programme was established in which a country's morphine consumption was considered to be an indicator of progress to improve cancer pain relief. ${ }^{1,5}$ Between 1984 and 1992, global consumption of morphine increased by nearly $300 \%$. $^{5,10}$ Since then morphine availability has increased worldwide and it has been introduced to many more countries. Other alternative opioids have also become more widely available, although as with morphine, availability and consumption is not uniform worldwide, eg, 94\% of oxycodone is consumed by USA, UK, Canada, Germany, and Australia. ${ }^{6}$

There have been very few large randomized controlled trials comparing different opioids thus there is little evidence suggesting superiority of one opioid over another. ${ }^{4}$ Some opioids differ in their mode of metabolism and therefore some are recommended as being safer in some circumstances than others, eg, alfentanil in renal failure. Table 1 details some of the common opioids used in the management of cancer pain. In a recent survey of 3030 cancer patients across Europe, morphine (oral or systemic) was the most commonly used strong opioid (50\%), followed by fentanyl $(14 \%)$, oxycodone $(4 \%)$, methadone $(2 \%)$ and hydromorphine (1\%). ${ }^{11}$ There are marked differences in the choice of 1 st line strong opioid in different countries, eg, in Belgium it is fentanyl while in Finland it is oxycodone. ${ }^{11}$ The differences in choice of opioid and opioid consumption was also shown in a study comparing opioid consumption in Denmark, Finland, Germany, Iceland, The Netherlands, Norway, and Sweden. ${ }^{12}$

\section{Recent advances in the use of opioids for cancer pain: opioid switching}

As more opioids have become available for use and as familiarity and knowledge about these different opioids increases, opioid switching has become a therapeutic maneuver which has become widespread in recent years.

Most patients who are prescribed morphine for cancer pain achieve good pain control without problematic sideeffects. These patients are known as "morphine responders". A significant proportion of patients however (up to $30 \%$ ) do not respond well to morphine. ${ }^{13}$ These "morphine nonresponders" present in a number of different ways: ${ }^{14}$

- Patients who achieve good analgesia but with intolerable side-effects

- Patients who do not achieve good analgesia because of dose-limiting side-effects

- Patients who do not achieve good analgesia but do not experience side-effects either, despite escalating morphine doses

Morphine "non-responders" often benefit from changing to an alternative opioid in a practice known as "opioid switching". The same principle applies for patients who do not respond well to any other opioid also. When used carefully the practice of opioid switching is a powerful therapeutic tool in the individualization of cancer pain management.

The terms "opioid switching" and "opioid rotation" are often used interchangeably in the literature. For the purpose of this review opioid switching refers to the use of an alternative opioid for the purpose of improving analgesia and 
reducing intolerable side-effects. Opioid rotation is taken to refer to the use of an alternative opioid because of availability, patient or physician choice or a change in the route of administration of the opioid. In some studies patients undergoing opioid switching and opioid rotation are included together. ${ }^{15,16}$

A Cochrane review in 2004 examined the evidence base for the effectiveness of opioid switching to improve drug tolerability. Fifty-two studies were included in this review, including 23 case reports, 15 retrospective studies or audits, and 14 prospective uncontrolled studies. All studies except one reported opioid switching as a beneficial clinical practice. The numbers of patients included in these studies tended to be small. At that time no randomized controlled trials or prospective controlled studies had been carried out in this area. Therefore the conclusion of the systematic review was that there was no substantial evidence to support the practice of opioid switching. The author called for further research in a number of areas: 1) to establish the true efficacy of opioid switching and 2) to determine which opioid should be used first line and second line. ${ }^{17}$

A further systematic review in 2006 suggested that opioid switching is associated with improvement in response to opioids in at least $50 \%$ of patients. ${ }^{14} \mathrm{~A}$ more detailed look at some of the larger studies suggests that careful opioid switching may in fact be associated with much higher response rates. Table 2 details the results of some of the largest studies in this area.

The only prospective case-controlled study of opioid switching was carried out using morphine as the first line strong opioid of choice for cancer pain with oxycodone as second line. The study, which included 186 patients, comprised 2 cohorts. 74\% (138/186) were morphine "responders", who had been on morphine for at least 4 weeks and who had good pain control with minimal side-effects. 26\% (48/186) were morphine "non-responders" who had either poor pain control and/or intolerable side-effects despite adequate morphine dose-titration. Switching from morphine to oxycodone in the morphine non-responder group resulted in an overall 96\% (179/186) good clinical outcome in terms of pain and side-effect profile. ${ }^{18}$

Two studies have examined the reasons why some patients do not have a successful outcome after opioid switching. In the study by Mercadante et al no association was found with clinical factors (including age of patient, gender), type or dose of opioid, pain type, the use of adjuvant medications or renal impairment. Patients in this study who had both poor pain control and adverse opioid effects were more likely to be unsuccessful in switching $(P=0.004)$. However the numbers of patients who did not respond to opioid switching in this study was small $(\mathrm{N}=15 / 118)$ therefore it is difficult to extrapolate these data into meaningful clinical practice. Eight patients in this study required intrathecal pain management. ${ }^{16}$ In the study by Riley et al 5/48 patients did not have a successful outcome after opioid switching. One of these required an epidural and the authors suggest that for 3 others anesthetic intervention would have been appropriate. ${ }^{18}$

If a switch from one opioid to another is unsuccessful a number of factors should be taken into consideration:

- A further opioid switch may be indicated. More than 1 opioid switch is sometimes required to achieve an optimum balance between analgesia and side-effects. ${ }^{16,18,19}$

- The pain may not be opioid responsive

- Central delivery of opioids may be required (via the epidural or intrathecal route)

- Other factors may be contributing to the side-effects experienced, eg, renal impairment, concurrent medications, factors related to the underlying disease.

After on opioid switch is undertaken it usually takes a few days to achieve a good outcome. Time to stabilization on the second opioid may be slightly longer if the patient was switched because of both pain and side-effects. ${ }^{16}$

The dose of the original opioid at which an opioid switch is required varies widely. In 1 study in which 54 patients were switched from morphine to methadone, the median daily morphine dose was $200 \mathrm{mg}$ (range 30 to $1000 \mathrm{mg}$ ). ${ }^{20}$ In another study the morphine equivalent daily dose was $577 \pm 1535 \mathrm{mg} .{ }^{19}$ In the prospective controlled study in which morphine non-responders were switched to oxycodone, the median dose of morphine at time of switching was $70 \mathrm{mg}$ (range 15 to $580 \mathrm{mg}$ ). ${ }^{18}$

Similarly the duration of the initial opioid therapy is variable. In one study patients were on the initial opioid for a median of 44 days (range 20 to 240 days). ${ }^{20}$ In another study the mean duration of the previous opioid therapy is reported as 25.8 weeks (180.6 days) (range 1 to 104 weeks). ${ }^{21}$ These data may suggest that there are 2 broad groups of patients which undergo opioid switching. The first group require switching shortly after initiation of the initial opioid, when the opioid dose is relatively low. The second group appear to become non-responsive to the initial opioid at either higher doses or after some time has elapsed, perhaps due to changes in the underlying painful state, disease, tolerance or some other contributing factor.

One of the most challenging aspects of switching from one opioid to another is deciding on the starting dose of 


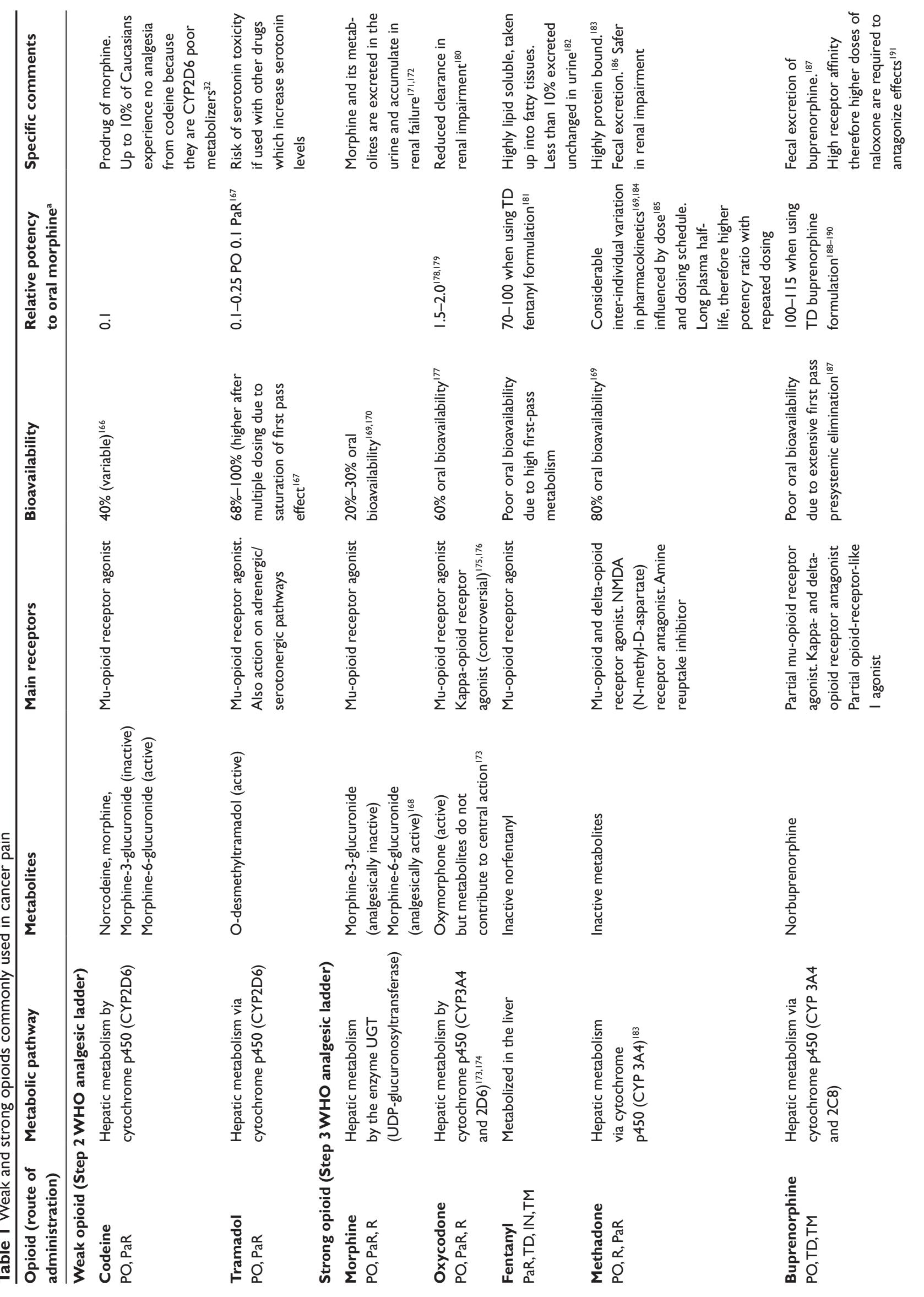




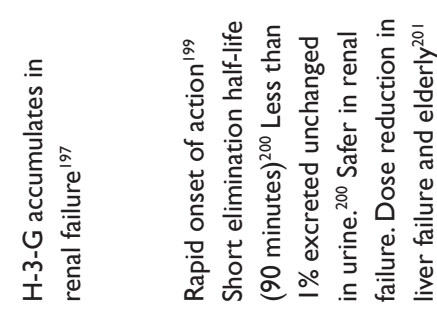

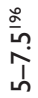

이
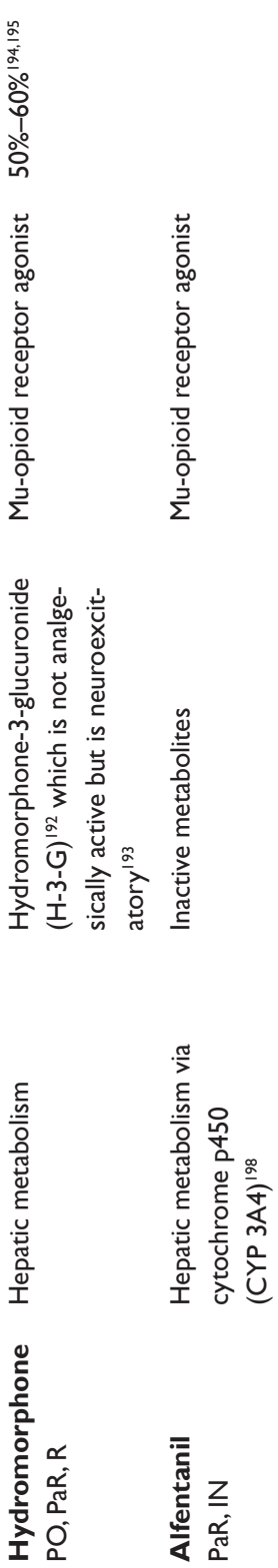

the second opioid. Although equianalgesic dose ratios are available, these are merely guidelines to the relative potencies of different opioids. These ratios were derived largely from single dose studies and do not take into account individual patient factors which may contribute to effect, such as previous opioid therapy, opioid tolerance or underlying disease. ${ }^{22,23}$ The reported equianalgesic dose ratios between opioids also may be quite variable depending on the study. The generally accepted equianalgesic dose ratio for oral morphine: oxycodone lies between $1: 1$ and $1: 2{ }^{22}$ In 1 study the median dose ratio of morphine: oxycodone was 1.7 with a broad range from 0.25 to $12 .{ }^{24}$ To make matters even more complicated the equianalgesic dose ratios may change according to the initial opioid dose, as has been proposed when switching morphine to methadone. ${ }^{20}$ One of the major factors contributing to the difficulties in determining the dose of the alternative opioid is the phenomenon of opioid tolerance. This is defined as a reduction in response to a drug after repeated administration. Tolerance to both opioid induced analgesia and side-effects may occur, although not necessarily in tandem together. ${ }^{25}$ Incomplete cross tolerance to different opioids exists, which may be explained in part by differing pharmacodynamic and pharmacokinetic factors. There appears to be no defined relationship between the dose of the initial opioid dose at time of switching and the final stable opioid dose after switching. ${ }^{14,16}$ In some cases opioid switching facilitates upward dose titration to achieve good analgesia. ${ }^{26}$ In others the final equivalent dose of opioid required was reduced. ${ }^{19}$ These data demonstrate the importance of individualized dose titration when switching opioids. ${ }^{14}$ Most authors recommend deciding on the dose when opioid switching in the context of a) the individual patient experience (ie, whether switching because of uncontrolled pain or side-effects) and b) the type of opioid used. Conservative dose ratios $^{22}$ and an initial dose reduction of the equianalgesic dose by $25 \%$ to $50 \%{ }^{22,23}$ are recommended with subsequent careful individualized dose titration.

\section{Recent advances in the use of opioids for cancer pain: pharmacogenetics}

To date no clinical factor has been identified which can fully explain inter-individual variation in response to opioids. One of the most recent advances in the use of opioids for cancer pain is the interest in pharmacogenetics: how an individual's genetic makeup may influence variability in opioid response. The hypothesis held by many researchers is that changes at a molecular level in opioid's pharmacokinetic 
Table 2 Efficacy of opioid switching

\begin{tabular}{|c|c|c|c|c|c|}
\hline Author & Type of study & $\begin{array}{l}\text { Number of } \\
\text { patients } \\
\text { undergoing } \\
\text { opioid switch }\end{array}$ & $\begin{array}{l}\text { Successful } \\
\text { outcome } \\
\text { after opioid } \\
\text { switching }\end{array}$ & Reason for switching & Comment \\
\hline Mercadante ${ }^{\mathrm{a}, 16}$ & $\begin{array}{l}\text { Prospective } \\
\text { uncontrolled study }\end{array}$ & 118 & $87 \%$ & $\begin{array}{l}\text { Uncontrolled pain } 15.2 \% \\
\text { Adverse effects } 28.8 \% \\
\text { Uncontrolled pain and } \\
\text { adverse effects } 50.8 \%\end{array}$ & $\begin{array}{l}\text { More than I opioid } \\
\text { switch required in } \\
7 \text { patients }(6 \%)\end{array}$ \\
\hline Riley ${ }^{18}$ & $\begin{array}{l}\text { Prospective } \\
\text { case-controlled } \\
\text { study }\end{array}$ & 48 & $87 \%$ & $\begin{array}{l}\text { Morphine responders compared } \\
\text { to morphine non responders: } \\
\text { Confusion and drowsiness }\left(P=5 \times 10^{-12}\right) \\
\text { Pain relief }\left(P=2.4 \times 10^{-6}\right) \\
\text { Nightmares }\left(P=5 \times 10^{-5}\right) \\
\text { Nausea }\left(P=7.3 \times 10^{-3}\right)\end{array}$ & $\begin{array}{l}\text { More than I opioid } \\
\text { switch required in } \\
4 \text { patients }(8.5 \%)\end{array}$ \\
\hline Wirz $^{21}$ & $\begin{array}{l}\text { Prospective } \\
\text { uncontrolled study }\end{array}$ & 50 & $64 \%$ & $\begin{array}{l}\text { Uncontrolled pain } 60 \% \\
\text { Sedation } 4 \% \\
\text { Itch } 2 \% \\
\text { Gastrointestinal effects } \\
\text { (nausea, constipation) } 40 \%\end{array}$ & \\
\hline Mercadante 202 & $\begin{array}{l}\text { Prospective } \\
\text { uncontrolled study }\end{array}$ & 52 & $80 \%$ & $\begin{array}{l}\text { Uncontrolled pain } 20 \% \\
\text { Adverse effects } 16 \% \\
\text { Uncontrolled pain and adverse effects } 64 \%\end{array}$ & \\
\hline Kloke*15 & $\begin{array}{l}\text { Retrospective } \\
\text { uncontrolled study }\end{array}$ & 103 & $65 \%$ & $\begin{array}{l}\text { Uncontrolled pain } 43 \% \\
\text { Adverse effects } 20 \% \\
\text { Uncontrolled pain and adverse effects } 15 \%\end{array}$ & \\
\hline De Stoutz ${ }^{19}$ & $\begin{array}{l}\text { Retrospective } \\
\text { uncontrolled study }\end{array}$ & 80 & $73 \%$ & $\begin{array}{l}\text { Uncontrolled pain } 16 \% \\
\text { Cognitive failure } 39 \% \\
\text { Hallucinations } 24 \% \\
\text { Myoclonus II\% } \\
\text { Nausea } 9 \% \\
\text { Local irritation } 1 \%\end{array}$ & $\begin{array}{l}\text { More than I opioid } \\
\text { switch required in } \\
\text { some patients }\end{array}$ \\
\hline
\end{tabular}

a Studies included changing from one opioid to another in order to improve pain and side-effect profile (ie, opioid switching) and also for other reasons (opioid rotation).

and pharmacodynamic pathways may be responsible for altered opioid response. ${ }^{27}$ These changes may be brought about by genetic variation at a DNA, RNA, or protein level. Pharmacogenetics is used in a number of areas of medicine including oncology and hematology to prospectively predict an individual's response to certain drugs including warfarin and irinotecan. ${ }^{28-30}$ In cancer pain management pharmacogentics may potentially allow prospective prediction of response to different opioids and facilitate choosing the correct dose of the correct drug for the correct patient, ie, personalized prescribing.

\section{DNA variation: single nucleotide polymorphisms}

DNA is made up of two opposing strands of nucleotides, with each nucleotide consisting of 1 of 4 bases (adenine [A], guanine [G], thymine [T], and cytosine [C]), a sugar and a phosphate bond. The most common type of genetic variation at the DNA level consists of a single change in a nucleotide at a particular position along the DNA strand: a single nucleotide polymorphism (SNP). SNPs may occur at any point in a gene and may be associated with a change in the amino acid sequence produced because a) they are located in a coding area of the gene b) through influence on transcription activity or c) because they are in linkage disequilibrium (in a non-random association) with another significant polymorphism.

One of the best characterized pharmacogenetic phenomena involves codeine. Codeine is metabolized to morphine via the genetically heterogenous enzyme CYP2D6 (debrisoquine/spartenine hydroxylase). ${ }^{31} \mathrm{Up}$ to $10 \%$ of Caucasians (and varying proportions of other populations) lack CYP2D6 activity. These are known as "poor metabolizers" and thus experience little analgesia from codeine, as compared to "extensive metabolizers. ${ }^{32}$ CYP2D6 gene duplication on the other hand is associated with ultra-rapid metabolism 
of codeine to morphine, found in $3 \%$ of Caucasians. ${ }^{33}$ There is a case report of fatal neonatal opioid toxicity in a child who was being breastfed by a CYP2D6 ultra-rapid metabolizing mother. ${ }^{34,35}$ Variation in at least 16 alleles has been shown to influence CYP2D6 activity. ${ }^{36}$ Recent data suggest that CYP2D6 phenotype also plays a role in response to tramadol. ${ }^{37}$ CYP2D6 gene duplication has been described as playing a role in development of respiratory depression on tramadol. ${ }^{38}$

The association between opioid response in cancer pain and number of other SNPs in different genes has also been studied (see Table 3). In most of these studies morphine has been the predominant opioid used, with sparse data on the genetics of response to other opioids. ${ }^{39}$ To date the numbers of patients in these studies have been small and the number of SNPs studied has been limited.

Most genes are chosen for genetic association studies on the basis of the biological role which they play in the pharmacokinetic or pharmacodynamic pathways for the drug. The most frequently studied candidate gene involved in morphine analgesia is OPRM which codes for the mu-opioid receptor. Two hundred fifty-eight validated SNPs have been identified along the OPRM gene. ${ }^{40}$ The most commonly studied polymorphism in OPRM is rs1799971, also known as A118G. This SNP which occurs in exon 1and results in an amino acid change (asparagine to aspartate) in the extracellular $\mathrm{N}$-terminus of the receptor. This in turn results in loss of a potential $\mathrm{N}$ terminus glycosylation site which theoretically may alter ligand binding and receptor dimerization. ${ }^{41,42}$ This SNP occurs with a frequency of $0 \%$ to $48.9 \%$, depending on the population being studied..$^{43}$ The actual functional consequences of this polymorphism are unclear. One study examined mRNA expression in human brain tissue and reported a reduction in mRNA and OPRM protein (receptor) levels associated with the variant. ${ }^{44} \mathrm{~A}$ further study demonstrated altered receptor binding affinity. ${ }^{45}$ Another study however reported no difference in binding affinities between wild type receptor and the mu-opioid receptor coded for by this variant. ${ }^{46}$

Clinical genetic association studies, although somewhat inconsistent, suggest that rs1799971 A118G does play a role in morphine response. The details of association with morphine response in cancer pain are found in Table 3. Generally these studies suggest that carriage of the $\mathrm{G}$ allele (variant) of this SNP is associated with a poor response to morphine for cancer pain. Patients with the $G$ allele tend to require higher doses of and experience less pain relief from morphine. ${ }^{47-49}$
This polymorphism was also been associated with differential central effects from morphine and M6G in a single blind two-way crossover study of 12 healthy volunteers who were administered IV morphine and IV M6G. The concentration of drug required to achieve $50 \%$ pupil constriction was used as a measure of drug potency. Serum concentrations of morphine and $\mathrm{M} 6 \mathrm{G}$ were measured at regular set intervals using liquid chromatography tandem mass spectrometry. Subjects with carrying the variant (ie, genotype AG or GG) required larger doses of $\mathrm{M} 6 \mathrm{G}$ to achieve $50 \%$ pupil constriction than subjects with AA (wild-type) genotype. There was no difference in the effects of morphine on pupil constriction between the genotypes. ${ }^{50}$

\section{RNA variation: spice variants}

A single stretch of DNA can result in a number of different protein products, mainly through RNA modification. Recent work into genetic variation at an RNA level has proposed the concept of multiple mu-opioid receptor subtypes through a process known as alternative splicing. Splicing refers to a process of post-transcription modification in which intronic material is removed and exons are joined together to form messenger RNA (mRNA). mRNA is subsequently translated into the protein product, which in the case of OPRM is the mu-opioid receptor. Different splicing products with potentially different functions can be formed through different arrangements of the exons in the mRNA.

The concept of multiple receptor subtypes is not new, suggested by a) incomplete cross tolerance between various mu-opioid receptor agonists ${ }^{51}$ and $b$ ) differential actions of mu-opioid receptor agonists and antagonists. ${ }^{52}$ Sophisticated rodent studies using inbred strains and knockout strains have further strengthened this concept. Mu-opioid receptor knockout mice demonstrate a complete loss of all mu-opioid receptors from the brain, suggesting that is mu-opioid receptor subtypes exists, they must be derived from the same gene. ${ }^{53}$ The CXBK mouse is an inbred strain which is poorly responsive to opioids. When administered morphine, these mice experience reduced analgesia. CXBK mice have reduced levels of OPRM1 mRNA, with subsequent reduced expression of mu-opioid receptors and less signal transduction. ${ }^{54} \mathrm{CXBK}$ mice, however, retain analgesic sensitivity to morphine-6-glucuronide (M-6-G), heroin and fentanyl, all mu-opioid receptor agonists, suggesting that M-6-G, heroin, and fentanyl act via a different mu-opioid receptor than morphine. ${ }^{55}$

The structure of the human mu-opioid receptor has been cloned. ${ }^{56}$ OPRM was initially thought to be made 


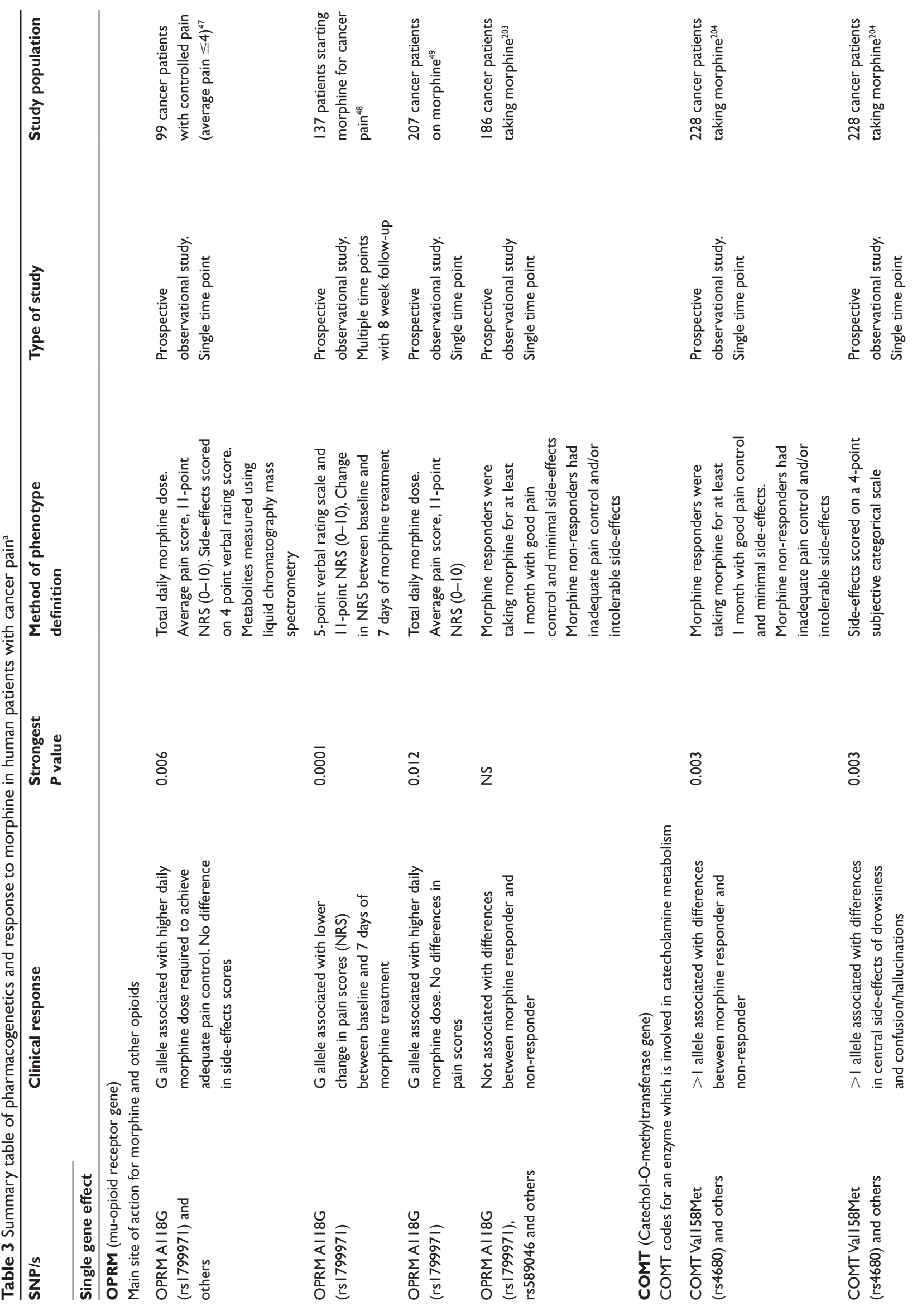




\begin{tabular}{|c|c|c|c|c|c|c|}
\hline 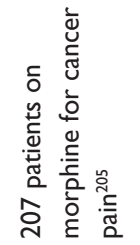 & 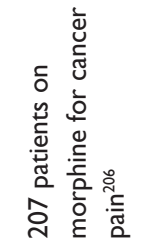 & 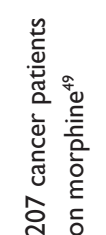 & 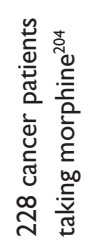 & 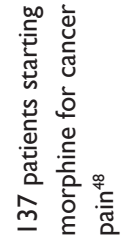 & 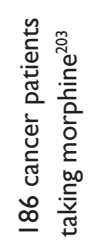 & 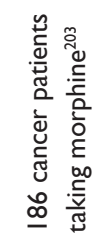 \\
\hline
\end{tabular}
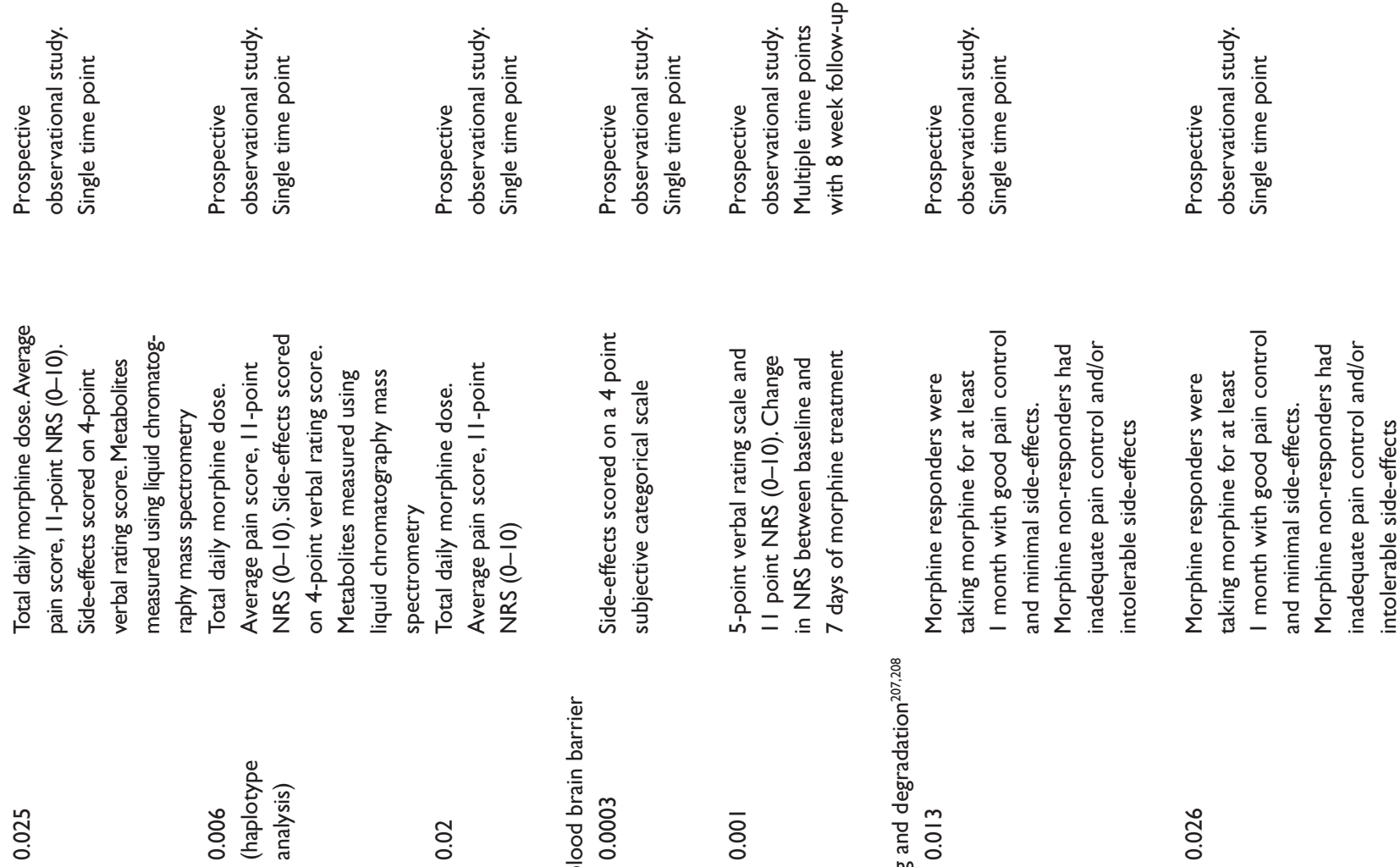

:
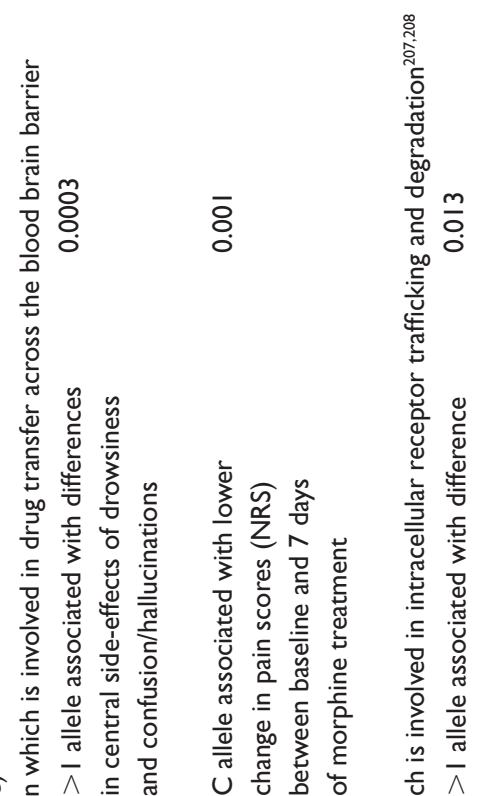

ํํํ
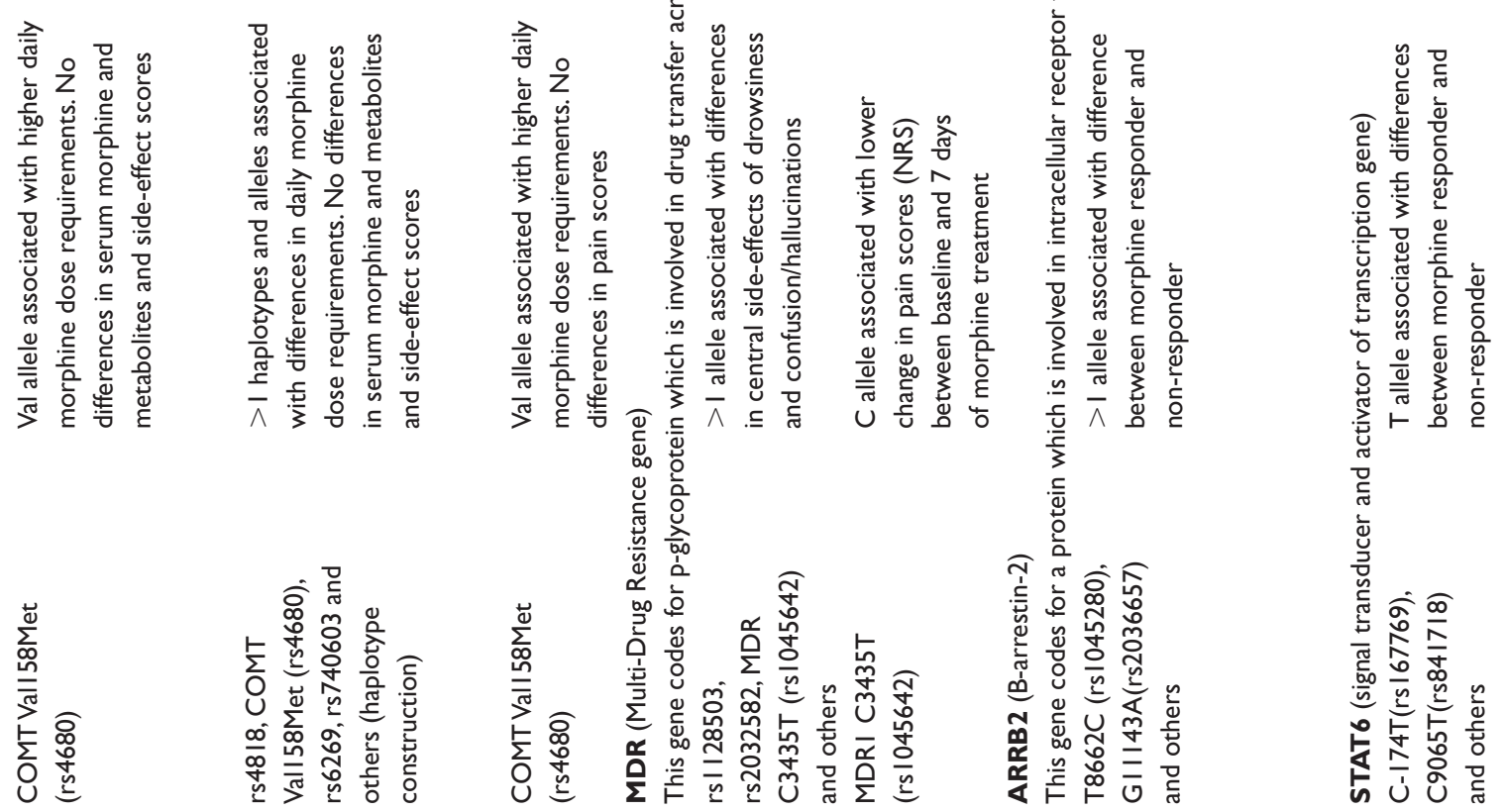


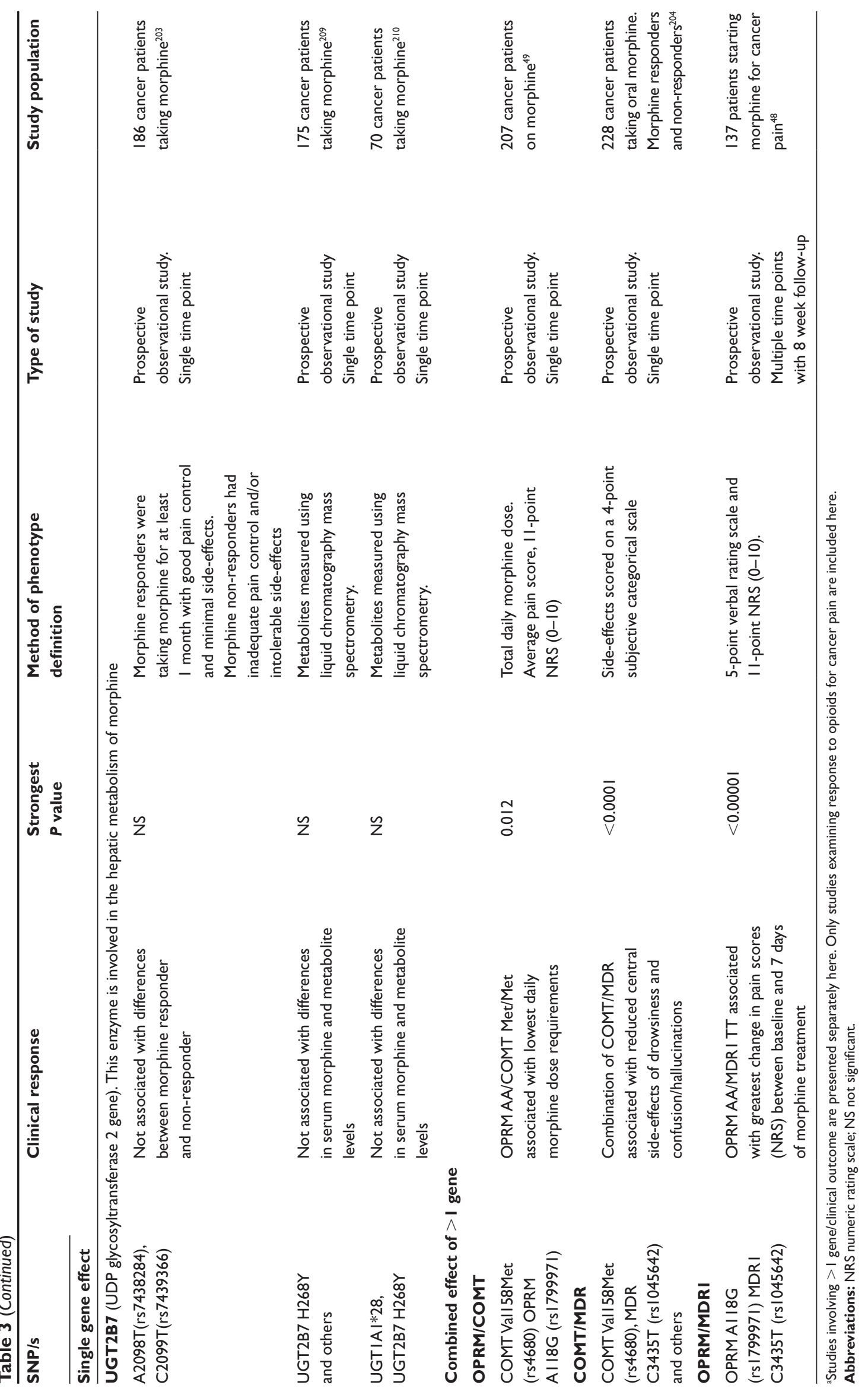


up of 4 exons (although more recent work suggests that it is in fact much more complex). ${ }^{57}$ Each exon is thought to be important for expression of different parts of the mu-opioid receptor. Exon 1 codes for the amino-terminal of the receptor and exons 1,2 and 3 code for the transmembrane domains and intra/extracelluler loops. ${ }^{58}$ Exon 4 codes for the distal portion of the carboxyl chain of the receptor which is important in coupling the receptor to intracellular signalling systems and events. Knockout animals and antisense probes have been used to examine the impact of blocking expression of parts of a gene of interest. Rodents without expression of exon 1 express significantly reduced morphine analgesia but retain sensitivity to M-6-G. ${ }^{59,60}$ Conversely, rodents with loss of exon 2 expression exhibit decreased M-6-G and not morphine analgesia. ${ }^{59}$ These data suggest that morphine and $\mathrm{M}-6-\mathrm{G}$ may act on different mu-opioid receptor subtypes, which may be brought about through variation at an RNA level. Even more intriguing is that although antisense blockade of exon 1 expression inhibited supraspinal morphine analgesia, it did not have any effect on spinal morphine analgesia, suggesting that perhaps different mu-opioid receptors are involved in both processes. ${ }^{61}$ Antisense blockade of exon 4 inhibited all morphine effects. ${ }^{59,61}$ Immunohistochemical labelling of mu-opioid receptor splice variants demonstrated differential distribution in the brain and spinal cord suggesting region specific processing of OPRM into different mu-opioid receptor subtypes. ${ }^{62}$

Practical challenges of examining human brain RNA means that most research in this area has been carried out in vitro using cell lines expressing mu-opioid receptors. ${ }^{63} 10$ human splice variants have been identified resulting from alternative splicing at exon $4 .^{63,64}$ Since exons 1 to 3 remain conserved, all of these splice variants bind mu-opioid agonists, but there are differences in terms of function, eg, receptor internalization and regional distribution. ${ }^{61}$ One study examining human brain tissue resected at time of temporal lobectomy for epilepsy demonstrated the presence of muopioid receptor splice variants though real time reverse transcriptase polymerase chain reaction. ${ }^{65}$

Alternative splicing of delta- and kappa-opioid receptors has also been demonstrated. ${ }^{66}$

Some human data support the role of splice variants in pain perception. A recent study by Diatchenko et al analyzed patterns of genetic material between mice and humans. Although there are differences in the structure of mouse and human OPRM, this study demonstrated that a) most mouse OPRM exons (of which there are 20) also exist in humans and $b$ ) the architecture of the human OPRM is probably more complex than previously thought. A SNP, rs563649, was identified which was associated with altered pain response and which was also associated with differential translation of splice variants of mu-opioid receptor. This SNP was not however statistically associated with morphine analgesic response to experimental ischemic pain. This study does suggest an association between genetic variation at a DNA level (SNPs) and variation at an RNA level. ${ }^{57}$

To date no studies have been carried out examining the association between opioid receptor expression/splice variants and response to morphine in cancer patients in the clinical setting.

\section{Protein variation: receptor dimerization}

Finally, even after the genetic code is translated into a protein product, modifications and variation in function may occur through the process of receptor dimerization.

Morphine acts primarily through the mu-opioid receptor. Animal studies have demonstrated that disruption of the mu-opioid receptor gene abolishes the analgesic effect of morphine despite the presence of functional delta- and kappa-opioid receptors. ${ }^{67}$ However binding studies suggest that morphine does bind to delta and kappa receptors, albeit with less affinity than to mu-opioid receptors. ${ }^{68,69}$ Although the role of delta- and kappa-opioid receptors in morphine response is not entirely clear, there is a suggestion that opioid receptors interact with each other and influence function. ${ }^{70-73}$ For example delta-receptor knockout mice do not develop analgesic tolerance to morphine. ${ }^{74}$ Opioid receptors can form homo and hetero-dimers, thus producing novel functional properties through altered ligand binding and differential intracellular receptor trafficking. ${ }^{75-77}$ Opioid receptor dimerization adds further to the complexity of inter-individual variation in opioid response. There have been no clinical studies examining the role of opioid receptor dimers on analgesic response to morphine for cancer pain.

\section{Recent advances in the use of opioids for cancer pain: alternative routes of opioid administration for breakthrough pain}

Breakthrough pain is defined as "a transient exacerbation of pain that occurs either spontaneously or in relation to a specific predictable or unpredictable trigger, despite relatively stable and adequately controlled background pain" ${ }^{78}$ There is some controversy surrounding the definition of this phenomenon but the reported prevalence is as high as $51 \%$ to $89 \% .{ }^{79-81}$ 
A number of issues arise when oral opioids are used to treat episodic breakthrough pain:

- Increasing the regular dose of opioids in a patient with stable background pain may result in intolerable sideeffects.

- Breakthrough pain often peaks to maximum intensity within minutes. ${ }^{82}$ The time to peak plasma concentration of oral morphine is 15 to 60 minutes. ${ }^{83}$ Therefore the effect of even immediate release (short-acting) oral opioids may last longer than the episode of breakthrough pain, making these drugs less suitable for pains which have a short duration/onset of action. ${ }^{84}$

In recent years there has been considerable interest in the development of alternative routes of opioid administration for the management of breakthrough pain, with particular emphasis on the oral transmucosal/buccal and also intranasal routes.

The oral mucosa has a rich blood supply and this route of drug administration avoids hepatic first-pass metabolism. ${ }^{85}$ Thus the onset of action of drugs administered transmucosally is potentially very rapid. ${ }^{86}$ Absorption is affected by lipophilicity of the drug, the fraction of drug which is ionized, the length of time with which the drug is in contact with the oral mucosa and also the $\mathrm{pH} .{ }^{85}$ Lipophilic drugs such as fentanyl and buprenorphine are more rapidly absorbed than more hydrophilic drugs such as morphine. ${ }^{87}$

There have been a number of studies examining the use of oral transmucosal fentanyl citrate (OTFC) for the management of breakthough cancer pain. OFTC is available as a lozenge on a stick which is rubbed on the inside of the cheek over an approximately 15 minute period. ${ }^{88}$ Approximately $25 \%$ of OFTC is absorbed via the buccal mucosa with the remaining $75 \%$ being swallowed. Overall the bioavailability of OFTC is approximately $50 \% .{ }^{89}$ The medium time to maximum plasma concentration is approximately 20 to 40 minutes. ${ }^{88,90} \mathrm{~T}_{\max }$ is similar regardless of dose. ${ }^{91} \mathrm{~A}$ study of 92 cancer patients demonstrated larger reductions in pain intensity and better pain relief with OTFC compared to placebo. ${ }^{92}$ A randomized double-blind dose titration study involving 65 cancer patients with breakthrough pain demonstrated a faster onset of analgesia with OFTC compared to the patient's usual rescue analgesia $(P<0.0001)$. In this study up to two episodes of breakthrough pain per day were treated with OTFC and all other episodes were treated with the patient's usual rescue opioid. ${ }^{93}$ Another double-blind double-dummy randomized cross-over study was carried out comparing OTFC and morphine sulphate immediate release (MSIR). Pain intensity and pain relief scores were noted at
$15,30,45$ and 60 minutes post dose. OTFC was associated with lower pain intensity and higher pain relief scores at all time points. A greater than $33 \%$ change in pain intensity at 15 minutes was seen in $42.3 \%$ of episodes of pain treated with OFTC compared to $31.8 \%$ of episodes treated with MSIR $(P<0.0001)$. In this study however only 69\% (93/134) of patients were titrated to an effective OFTC dose, with $31 \%$ (41/134) withdrawing during the OFTC titration phase. Only 75/93 patients used both OFTC and MSIR and thus were included in the efficacy analysis. ${ }^{94}$

Interestingly there appears to be no relationship between the effective dose of OFTC and the stable background opioid dose. ${ }^{93-95}$ Dose titration to an effective dose has been shown to be successful in 67 to $74 \%$ of patients. ${ }^{93,94,96}$ The usefulness of OFTC is limited if the patient has xerostomia ${ }^{97}$ or if the patient cannot manage the technique of applying it to the buccal mucosa.

More recently a novel effervescent transmucosal fentanyl buccal tablet (FBT) has been launched. This medication is designed to dissolve in 10 minutes when placed between the upper gum and cheek above a molar tooth. ${ }^{98}$ In a healthy volunteer open label cross-over study $(\mathrm{N}=26)$ comparing OFTC and transmucosal FBT, the latter was found to have a higher absolute bioavailability ( 0.47 and 0.65 respectively). The time to maximum plasma concentration was shorter for transmucosal FBT compared to OFTC (47 and 91 minutes respectively).$^{98}$ Of note the $\mathrm{T}_{\text {max }}$ for OFTC in this study was actually considerably longer than reported in previous data, as discussed above. ${ }^{88,90}$ Transmucosal FBT appears better than placebo for the management of breakthrough pain in cancer patients ${ }^{99}$ It appears to be well tolerated in patients with mucositis, although the numbers involved in this study were small and the patients only experienced mild oral symptoms. ${ }^{100}$

Sublingual and intranasal fentanyl preparations have also been studied for breakthrough cancer pain. ${ }^{101-103}$ Sublingual and intranasal sufentanil is also used although this drug is not available in some countries. The data on sufentanil in cancer-related breakthrough pain consists of case series and small studies. ${ }^{104,105}$

\section{Recent advances in the use of opioids for cancer pain: opioid antagonists for opioid-induced constipation}

Constipation is one of the most common and troublesome side-effects of opioid medication. The published prevalence 
of constipation amongst patients taking opioids ranges from $50 \%$ to $100 \%{ }^{106,107}$ Although the pathogenesis of constipation in cancer patients is multi-factorial, ${ }^{108}$ opioid medication plays a key role. ${ }^{106}$ There appears to be no dose-response relationship between opioids and constipation and unlike other side-effects such as drowsiness it is thought that for many patients tolerance to constipation is less likely to occur. $^{109,110}$

Unlike opioid-analgesia, opioid-induced constipation is thought to be mediated predominately by peripheral rather than central mechanisms: ${ }^{111}$

- In vitro experiments have demonstrated inhibitory effect of opioids on isolated gut muscle preparations. ${ }^{112}$

- The constipating effects of centrally administered morphine are abolished in animals in which the intestine has been rendered refractory to central influences through vagal resection. In the same animals however, subcutaneous morphine still produced anti-diarrheal action. ${ }^{113}$

- Peripherally restricted opioid agonists such as loperamide which do not cross the blood-brain barrier also cause a reduction in gut transit. ${ }^{114}$

$\mathrm{Mu}-$, delta-, and kappa-opioid receptors are found throughout the gastrointestinal (GI) tract. Mu- and delta-opioid receptors are found in both the myenteric and submucosal neurones while kappa-opioid receptors are predominately localized to the myenteric plexus. ${ }^{115}$ Morphine is thought to act directly on these peripheral opioid receptors in the bowel. Morphine administered either intravenously or intra-peritoneally accumulates in the GI lumen. ${ }^{116} \mathrm{Mu}$-opioid receptor knockout mice studies demonstrate a key role of mu-opioid receptors in the role of opioid-induced constipation. ${ }^{117}$

Opioid receptor activation by opioid agonists causes a reduction in synaptic neurotransmitter release through activation of potassium channels, ${ }^{118}$ inhibition of calcium channels ${ }^{119}$ and a reduction in cAMP production. ${ }^{120}$ The overall effect is a reduction in acetylcholine release. ${ }^{106}$ Opioids increase gut transit time and reduce the amount of fluid in the gut lumen. Forward propulsive contractions are inhibited, the stool spends a longer time in the gut lumen thus more fluid is reabsorbed and the stool becomes hard and dry. Opioids also have an indirect inhibitory effect on luminal fluid secretion via a complex mechanism involving 5-HT2 receptors, $\alpha 2$-adrenoceptors and noradrenaline release. ${ }^{121}$

The management of constipation has traditionally been based around oral and rectal laxative use. A number of different agents are available but to date there is no evidence to suggest that any one laxative is superior to another, mainly because there have been few studies in this area. ${ }^{122}$ In recent years there has been a growing interest in the use of opioid receptor antagonists for the management of opioid-induced constipation. Theoretically opioid receptor blockade by an agent which does not cross the blood brain barrier would inhibit peripherally mediated GI side-effects without interruption of centrally mediated opioid analgesia. Three opioid receptor antagonists have been studied for this purpose: naloxone, methylnaltrexone, and alvimopan.

\section{Naloxone}

Naloxone is a pan-opioid receptor antagonist with a high affinity for mu-opioid receptors. Systemically administered naloxone is used to reverse life-threatening opioid toxicity and acts both peripherally and centrally. Oral naloxone however undergoes significant hepatic first pass glucuronidation to produce inactive metabolites, ${ }^{123}$ resulting in a very low (2\%) oral bioavailability. ${ }^{124}$ The role of oral naloxone as a peripheral opioid antagonist in cancer patients has been examined in a number of small early studies with good effect. ${ }^{125-127}$ These studies however all demonstrated that the risk of precipitating pain or opioid withdrawal is substantial. The study by Sykes $(\mathrm{N}=17)$ investigated the relationship between the dose of morphine and naloxone recommended a daily naloxone dose of $20 \%$ of the daily morphine dose, to a maximum of $5 \mathrm{mg} .{ }^{127}$ Another study in 22 cancer patients examined the relationship between morphine and effective naloxone dose when naloxone was titrated up to a maximum of $36 \mathrm{mg} /$ day over a 4-day period to laxative use and opioid withdrawal (measured using a modified Himmelsbach withdrawal scale). $23 \%(4 / 17)$ patients who completed the study experienced withdrawal symptoms. There was no relationship demonstrated between morphine and effective naloxone dose. ${ }^{128} \mathrm{~A}$ further study in 9 patients demonstrated again that reversal of analgesia can still occur even when using lower doses of oral naloxone (6 to $12 \mathrm{mg} /$ day). ${ }^{129}$

Recently there has been increased interest in the use of fixed dose combination of prolonged release (PR) oral oxycodone/naloxone as a method to provide analgesia while preventing opioid-induced constipation. A multicentre prospective placebo-controlled randomized double-blind parallel group phase II trial of 202 patients with severe chronic pain concluded that a 2:1 oxycodone:naloxone ratio was optimal in terms of safety and efficacy. Only $2.5 \%$ of study participants in this study had a cancer diagnosis. ${ }^{130}$ There was no significant difference in the mean pain intensities between treatment groups but there was an improvement in bowel function according to naloxone dose $(\mathrm{p}<0.05)$. Opioid withdrawal was not formally assessed in this study. 
Similar studies with 12 week follow-up periods comparing oxycodone/naloxone (2:1 ratio) PR with oxycodone PR alone demonstrated a significant improvement in bowel function in those taking the oxycodone/naloxone combination $(P<0.0001) .{ }^{131,132}$ The maximum oxycodone dose (as part of the oxycodone/naloxone combination) in these studies was $80 \mathrm{mg}$ /day. Studies involving higher opioid doses with longer follow-up are warranted. This efficacy of this combination of oxycodone/naloxone combination in a predominately cancer population has not yet been reported.

\section{Methylnaltrexone}

Methylnaltrexone is a quaternary opioid antagonist which does not readily cross the blood brain barrier because of its reduced lipid solubility and increased polarity. ${ }^{133}$ It is a non-selective opioid antagonists with preferential mu-opioid receptor binding. ${ }^{134}$

Methylnaltrexone was originally studied in healthy volunteers who were given intravenous placebo, placebo + morphine or methylnaltrexone + morphine. Methylnaltrexone significantly prevented morphine-induced decrease in oral-cecal transit but did not affect morphine analgesia. ${ }^{135}$ A randomized placebo-controlled trial was carried out involving 22 subjects who were enrolled on a methadone maintainance programme. All subjects who received methylnaltrexone (intravenous) had a laxation response without opioid withdrawal or significant side-effects. ${ }^{136}$

A large randomized placebo-controlled phase III study using subcutaneous methylnaltrexone in patients with advanced illness has been published recently. ${ }^{137}$ Study subjects were administered $0.15 \mathrm{mg} / \mathrm{kg}$ methylnaltrexone SC (subcatenous) or placebo every second day for 2 weeks. The primary endpoints of this study were the proportion of subjects who had a rescue-free laxation (without the use of an enema or suppository) within 4 hours of the first dose and the proportion that had a rescue-free laxation within 4 hours after 2 or more of the first 4 doses. Subjects were also assessed for overall pain scores and opioid withdrawal. Forty-eight percent of patients receiving methylnaltrexone had a rescue-free laxation within the first 4 hours after the first dose, compared to $15 \%$ who received placebo $(P<0.001)$. Over the course of the first 4 doses, the proportion of patients having a rescue-free laxation within 4 hours ranged from $38 \%$ to $48 \%$ in patients administered methylnaltrexone and $7 \%$ to $15 \%$ in those given placebo. Approximately $50 \%$ of patients who had a rescue-free laxation within 4 hours had a response within 30 minutes, suggesting a rapid onset of action. There were no differences in pain scores between the methylnaltrexone and placebo groups and there was no evidence of significant opioid withdrawal. Only 59\% (78/133) of study patients had a cancer diagnosis. ${ }^{137}$ A similar study in 154 patients with advanced illness receiving a single dose of 0.15 or $0.3 \mathrm{mg} / \mathrm{kg} \mathrm{SC}$ methylnaltrexone or placebo demonstrated a laxation within 4 hours for $58 \%$ to $62 \%$ of patients, depending on the dose administered. ${ }^{138}$ The authors of both these studies suggest that the reason why there appears to be a substantial proportion of patients who did not have a response to methylnaltrexone is perhaps due to non-opioid causes of constipation or constipation being mediated by central mechanisms. ${ }^{137,138} \mathrm{SC}$ methylnaltrexone is licensed in the UK for palliative care patients as either 8 or $12 \mathrm{mg}$ depending on body weight. ${ }^{139}$

Oral methylnaltrexone has not been studied in cancer patients to date however there are data to suggest that it may be efficacious. In a small $(\mathrm{N}=14)$ randomized controlled double-blind study of healthy volunteers methylnaltrexone prevented morphine-induced inhibitory effects on gut transit. There was no correlation between plasma concentrations of methylnaltrexone and the gut transit time and less than $1 \%$ of methylnaltrexone was excreted unchanged in the urine after 6 hours. Therefore the authors concluded that oral methylnaltrexone has a direct local bowel action. ${ }^{140} \mathrm{~A}$ further randomized controlled trial using an enteric-coated oral formulation demonstrated similarly efficacious results. ${ }^{141}$

\section{Alvimopan}

Alvimopan is a large oral peripherally restricted opioid antagonist with high affinity for mu-opioid receptors. ${ }^{142}$ It is metabolized in the gut. ${ }^{143}$ Systemic absorption ranges from $0.03 \%$ in dogs to $6 \%$ in humans. ${ }^{144}$ Alvimopan reversed morphine-induced GI transit changes (as measured with the hydrogen breath test) in a double-blind, placebo-controlled, randomized, cross-over study in 14 volunteers. As part of the same study 45 patients undergoing tooth extraction were administered IV (intravenous) morphine and either oral alvimopan or placebo. Alvimopan did not alter analgesia and did not affect pupil constriction, confirming a lack of central activity. ${ }^{145}$ Oral alvimopan has also been studied with positive effect in post-operative ileus which is thought to be caused by activation of endogenous opioid receptors after bowel handling and also by exogenous opioids administered for pain control. ${ }^{146-148}$ Alvimopan was studied in a large trial $(\mathrm{N}=522)$ of patients taking opioids for chronic non-cancer pain. It was associated with an increase in the number of spontaneous bowel movements compared to placebo ( $p<0.001)$. Adverse effects reported in this study included abdominal pain, nausea 
and diarrhea. ${ }^{149}$ In another large study involving 148 patients on opioids for non-malignant pain and 20 patients on opioid maintenance therapy for opioid abuse, a statistically larger proportion of patients receiving alvimopan than placebo achieved the primary endpoint of having a bowel motion within 8 hours. ${ }^{150} \mathrm{~A}$ large study in patients with cancer pain has been carried out but the final results have not yet been published fully. Concern about cardiovascular side-effects have been raised. ${ }^{151-153}$

Endogenous opioids are thought to play a role in the physiological regulation of gut function. ${ }^{154-156}$ Studies with opioid receptor antagonists support this idea. Early studies on isolated pieces of human ileum demonstrated increased muscle contraction when bathed in methylnaltrexone, even in the absence of morphine. ${ }^{157}$ Furthermore, in the absence of morphine, repeated intravenous administration in healthy human volunteers demonstrated a significant reduction in gut transit time (as measured by the hydrogen breath test). ${ }^{158}$ Oral naloxone has been shown to improve gut function in patients with chronic idiopathic constipation, although the numbers of patients studied was small. ${ }^{159}$ In vitro studies using guinea pig ileum demonstrated that alvimopan increases contractions and mechanical activity in morphine-naïve animals. ${ }^{160}$

The development of opioid receptor antagonists is exciting, however a recent Cochrane review urges some caution. ${ }^{153}$ These agents have not been directly compared against each other and they have not been compared to best current clinical practice with oral and rectal laxatives. In some of the larger studies, as constipation was a pre-requisite to entering the study, these individuals were clearly on an inadequate laxative regimen from the outset. ${ }^{137,149}$ Most data suggest that these agents are more efficacious than placebo in improving opioid-induced bowel dysfunction. Long-term safety data, however, is warranted. Animal studies suggest that chronic use of opioid-receptor antagonists may actually result in an increase in the number of receptors which in turn may lead to increased sensitivity to the constipating effect of opioid agonists and a resultant dependence on opioid antagonists. ${ }^{161}$ It has also been suggested that the effects of opioid antagonists may in fact be proportional to the degree of opioid agonist tolerance and that patients on higher doses of opioid agonists may in fact be more at risk of adverse effects from drugs such as naloxone. ${ }^{162}$

\section{Opioids for cancer pain: recent advances and future directions}

Opioids are the mainstay of treatment for moderate to severe cancer pain. Unfortunately cancer pain is often managed inadequately. In a recent survey of 5084 cancer patients across Europe and Israel, 56\% experienced moderate to severe pain at least monthly. ${ }^{163}$ In another European study of 3030 palliative care patients, $32 \%$ had moderate or severe pain. ${ }^{11}$ Although the variety and availability of different opioids has increased, the greatest advance in the use of opioids for cancer pain is undoubtedly an improved understanding of their mechanism of action. Physicians and researchers have become increasingly aware of marked inter-individual variation in response to opioids for cancer pain in terms of pain and side-effects. Exciting research in the field of pharmacogenomics promises a greater understanding of the mechanisms underlying this variation. Novel modes of administration and the use of peripherally restricted opioid antagonists allow greater pain control while minimizing troublesome side-effects. There have been major advances in the use of functional neuroimaging (such as functional magnetic resonance imaging, fMRI) to identify and measure areas of the brain which are involved in pain perception ${ }^{164}$ and also response to opioids. ${ }^{165}$ This technology may be of use in the future in furthering our understanding of pain mechanisms and inter-individual variation in opioid response. The future of opioids for cancer pain lies in personalized prescribing ie, the tailored prescription of the correct dose of the correct drug for the individual patient.

\section{Disclosures}

The authors declare no conflict of interest.

\section{References}

1. World Health Organization. Cancer Pain Relief. 2nd ed. World Health Organization; 1996.

2. Zech DF, Grond S, Lynch J, Hertel D, Lehmann KA. Validation of World Health Organization Guidelines for cancer pain relief: a 10-year prospective study. Pain. 1995;63(1):65-76.

3. Meuser T, Pietruck C, Radbruch L, Stute P, Lehmann KA, Grond S. Symptoms during cancer pain treatment following WHO-guidelines: a longitudinal follow-up study of symptom prevalence, severity and etiology. Pain. 2001;93(3):247-257.

4. Hanks GW, Conno F, Cherny N, Hanna M, Kalso E, McQuay HJ, et al. Morphine and alternative opioids in cancer pain: the EAPC recommendations. Br J Cancer. 2001;84(5):587-593.

5. Joranson DE. Availability of opioids for cancer pain: recent trends, assessment of system barriers, New World Health Organization guidelines, and the risk of diversion. J Pain Symptom Manage. 1993;8(6):353-360.

6. International Narcotics Control Board ARPr, United Nations. Narcotic drugs - estinated world requirements for 2008 - statistics for 2006. Part 4: Statistical information on narcotic drugs. International Narcotics Control Board 2007 [cited 2009 Jun 9]; Available from: URL: www.incb. org/pdf/technical-reports/narcotic-drugs/2007/part_four_2007.pdf.

7. Von Roenn JH, Cleeland CS, Gonin R, Hatfield AK, Pandya KJ. Physician attitudes and practice in cancer pain management. A survey from the Eastern Cooperative Oncology Group. Ann Intern Med. 1993;119(2):121-126. 
8. International Narcotics Control Board ARPr. Ensuring access to pain treatment is vital and possible says INCB. International Narcotics Control Board 2008 [cited 2009 Jun 9]; Available from: URL: www. incb.org/pdf/annual-report/2007/en/04-press-release.pdf

9. Stjernsward J. WHO cancer pain relief programme. Cancer Surv. 1988;7(1):195-208.

10. World Health Organization. Cancer Pain Relief With a Guide to Opioid Availability. 2nd ed. Geneva: 1996.

11. Klepstad P, Kaasa S, Cherny N, Hanks G, De CF. Pain and pain treatments in European palliative care units. A cross sectional survey from the European Association for Palliative Care Research Network. Palliat Med. 2005;19(6):477-484.

12. Hamunen K, Laitinen-Parkkonen P, Paakkari P, Breivik H, Gordh T, Jensen $\mathrm{NH}$, et al. What do different databases tell about the use of opioids in seven European countries in 2002? Eur J Pain. 2008;12(6):705-715.

13. Cherny N, Ripamonti C, Pereira J, Davis C, Fallon M, McQuay H, et al. Strategies to manage the adverse effects of oral morphine: an evidence-based report. J Clin Oncol. 2001;19(9):2542-2554.

14. Mercadante S, Bruera E. Opioid switching: a systematic and critical review. Cancer Treat Rev. 2006;32(4):304-315.

15. Kloke M, Rapp M, Bosse B, Kloke O. Toxicity and/or insufficient analgesia by opioid therapy: risk factors and the impact of changing the opioid. A retrospective analysis of 273 patients observed at a single center. Support Care Cancer. 2000;8(6):479-486.

16. Mercadante S, Ferrera P, Villari P, Casuccio A, Intravaia G, Mangione S. Frequency, indications, outcomes, and predictive factors of opioid switching in an acute palliative care unit. J Pain Symptom Manage. 2009;37(4):632-641.

17. Quigley C. Opioid switching to improve pain relief and drug tolerability. Cochrane Database Syst Rev. 2004;(3):CD004847.

18. Riley J, Ross JR, Rutter D, Wells AU, Goller K, Du BR, et al. No pain relief from morphine? Individual variation in sensitivity to morphine and the need to switch to an alternative opioid in cancer patients. Support Care Cancer. 2006;14(1):56-64.

19. de Stoutz ND, Bruera E, Suarez-Almazor M. Opioid rotation for toxicity reduction in terminal cancer patients. J Pain Symptom Manage. 1995;10(5):378-384.

20. Benitez-Rosario MA, Salinas-Martin A, guirre-Jaime A, PerezMendez L, Feria M. Morphine-methadone opioid rotation in cancer patients: analysis of dose ratio predicting factors. J Pain Symptom Manage. 2009;37(6):1061-1068.

21. Wirz S, Wartenberg HC, Elsen C, Wittmann M, Diederichs M, Nadstawek J. Managing cancer pain and symptoms of outpatients by rotation to sustained-release hydromorphone: a prospective clinical trial. Clin J Pain. 2006;22(9):770-775.

22. Anderson R, Saiers JH, Abram S, Schlicht C. Accuracy in equianalgesic dosing. conversion dilemmas. J Pain Symptom Manage. 2001;21(5):397-406.

23. Gammaitoni AR, Fine P, Alvarez N, McPherson ML, Bergmark S. Clinical application of opioid equianalgesic data. Clin J Pain. 2003;19(5):286-297.

24. Ross JR, Riley J, Quigley C, Welsh KI. Clinical pharmacology and pharmacotherapy of opioid switching in cancer patients. Oncologist. 2006;11(7):765-773.

25. Mercadante S. Opioid rotation for cancer pain: rationale and clinical aspects. Cancer. 1999;86(9):1856-1866.

26. Narabayashi M, Saijo Y, Takenoshita S, Chida M, Shimoyama N, Miura T, et al. Opioid rotation from oral morphine to oral oxycodone in cancer patients with intolerable adverse effects: an open-label trial. Jpn J Clin Oncol. 2008;38(4):296-304.

27. Kasai S, Hayashida M, Sora I, Ikeda K. Candidate gene polymorphisms predicting individual sensitivity to opioids. Naunyn Schmiedebergs Arch Pharmacol. 2008;377(4-6):269-281.

28. Innocenti F, Undevia SD, Iyer L, Chen PX, Das S, Kocherginsky M, et al. Genetic variants in the UDP-glucuronosyltransferase 1A1 gene predict the risk of severe neutropenia of irinotecan. J Clin Oncol. 2004;22(8):1382-1388.
29. Iyer L, Das S, Janisch L, Wen M, Ramirez J, Karrison T, et al. UGT1A $1 * 28$ polymorphism as a determinant of irinotecan disposition and toxicity. Pharmacogenomics J. 2002;2(1):43-47.

30. Schwarz UI, Ritchie MD, Bradford Y, Li C, Dudek SM, FryeAnderson A, et al. Genetic determinants of response to warfarin during initial anticoagulation. N Engl J Med. 2008;358(10):999-1008.

31. Dayer P, Desmeules J, Leemann T, Striberni R. Bioactivation of the narcotic drug codeine in human liver is mediated by the polymorphic monooxygenase catalyzing debrisoquine 4-hydroxylation (cytochrome P-450 dbl/bufI). Biochem Biophys Res Commun. 1988;152(1):411-416.

32. Sindrup SH, Brosen K, Bjerring P, rendt-Nielsen L, Larsen U, Angelo HR, et al. Codeine increases pain thresholds to copper vapor laser stimuli in extensive but not poor metabolizers of sparteine. Clin Pharmacol Ther. 1990;48(6):686-693.

33. Kirchheiner J, Schmidt H, Tzvetkov M, Keulen JT, Lotsch J, Roots I, et al. Pharmacokinetics of codeine and its metabolite morphine in ultrarapid metabolizers due to CYP2D6 duplication. Pharmacogenomics $J$. 2007;7(4):257-265.

34. Koren G, Cairns J, Chitayat D, Gaedigk A, Leeder SJ. Pharmacogenetics of morphine poisoning in a breastfed neonate of a codeine-prescribed mother. Lancet. 2006;368(9536):704.

35. Madadi P, Ross CJ, Hayden MR, Carleton BC, Gaedigk A, Leeder JS, et al. Pharmacogenetics of neonatal opioid toxicity following maternal use of codeine during breastfeeding: a case-control study. Clin Pharmacol Ther. 2009;85(1):31-35.

36. Sachse C, Brockmoller J, Bauer S, Roots I. Cytochrome P450 2D6 variants in a Caucasian population: allele frequencies and phenotypic consequences. Am J Hum Genet. 1997;60(2):284-295.

37. Stamer UM, Lehnen K, Hothker F, Bayerer B, Wolf S, Hoeft A, et al. Impact of CYP2D6 genotype on postoperative tramadol analgesia. Pain. 2003;105(1-2):231-238.

38. Stamer UM, Stuber F, Muders T, Musshoff F. Respiratory depression with tramadol in a patient with renal impairment and CYP2D6 gene duplication. Anesth Analg. 2008;107(3):926-929.

39. Skorpen F, Laugsand EA, Klepstad P, Kaasa S. Variable response to opioid treatment: any genetic predictors within sight? Palliat Med. 2008;22(4):310-327.

40. Riva A, Kohane IS. A SNP-centric database for the investigation of the human genome. BMC Bioinformatics. 2004 26;5:33.

41. Chaturvedi K, Shahrestanifar M, Howells RD. $\mu$ opioid receptor: role for the amino terminus as a determinant of ligand binding affinity. Mol Brain Res. 2000;76:64-72.

42. Mayer P, Hollt V. Pharmacogenetics of opioid receptors and addiction. Pharmacogenet Genomics. 2006;16(1):1-7.

43. NCBI. HapMap frequency data on SNP databbase, NCBI (National Centre for Biotechnology Information). NCBI 2009 [cited 2009 Jun 20]; Available from: URL: www.ncbi.nlm.nih.gov

44. Zhang Y, Wang D, Johnson AD, Papp AC, Sadee W. Allelic expression imbalance of human mu opioid receptor (OPRM1) caused by variant A118G. J Biol Chem. 2005;280(38):32618-32624.

45. Bond C, LaForge KS, Tian M, Melia D, Zhang S, Borg L, et al. Singlenucleotide polymorphism in the human mu opioid receptor gene alters beta-endorphin binding and activity: possible implications for opiate addiction. Proc Natl Acad Sci U S A. 1998;95(16):9608-9613.

46. Befort K, Filliol D, Decaillot FM, Gaveriaux-Ruff C, Hoehe MR, Kieffer BL. A single nucleotide polymorphic mutation in the human [micro]-opioid receptor severely impairs receptor signaling. J Biol Chem. 2001;276(5):3130-3137.

47. Klepstad P, Rakvag TT, Kaasa S, Holthe M, Dale O, Borchgrevink PC, et al. The $118 \mathrm{~A}>\mathrm{G}$ polymorphism in the human micro-opioid receptor gene may increase morphine requirements in patients with pain caused by malignant disease. Acta Anaesthesiol Scand. 2004;48(10):1232-1239.

48. Campa D, Gioia A, Tomei A, Poli P, Barale R. Association of ABCB1/ MDR1 and OPRM1 gene polymorphisms with morphine pain relief. Clin Pharmacol Ther. 2008;83(4):559-566 
49. Reyes-Gibby CC, Shete S, Rakvag T, Bhat SV, Skorpen F, Bruera E, et al. Exploring joint effects of genes and the clinical efficacy of morphine for cancer pain: OPRM1 and COMT gene. Pain. 2007;130(1-2):25-30.

50. Lotsch J, Skarke C, Grosch S, Darimont J, Schmidt H, Geisslinger G. The polymorphism A118G of the human mu-opioid receptor gene decreases the pupil constrictory effect of morphine-6-glucuronide but not that of morphine. Pharmacogenetics. 2002;12(1):3-9.

51. Pasternak GW. Incomplete cross tolerance and multiple mu opioid peptide receptors. Trends Pharmacol Sci. 2001;22(2):67-70.

52. Portoghese PS, Larson DL, Sayre LM, Fries DS, Takemori AE. A novel opioid receptor site directed alkylating agent with irreversible narcotic antagonistic and reversible agonistic activities. J Med Chem. 1980;23(3):233-234.

53. Clarke S, Kitchen I. Opioid analgesia: new information from gene knockout studies. Curr Opin Anaesthesiol. 1999;12:609-614.

54. Ikeda K, Ide S, Han W, Hayashida M, Uhl GR, Sora I. How individual sensitivity to opiates can be predicted by gene analyses. Trends Pharmacol Sci. 2005;26(6):311-317.

55. Rossi GC, Brown GP, Leventhal L, Yang K, Pasternak GW. Novel receptor mechanisms for heroin and morphine- 6 beta-glucuronide analgesia. Neurosci Lett. 1996 20;216(1):1-4.

56. Wang JB, Johnson PS, Persico AM, Hawkins AL, Griffin CA, Uhl GR Human mu opiate receptor. cDNA and genomic clones, pharmacologic characterization and chromosomal assignment. FEBS Lett. 1994;338(2):217-222.

57. Shabalina SA, Zaykin DV, Gris P, Ogurtsov AY, Gauthier J, Shibata K, et al. Expansion of the human \{micro\}-opioid receptor gene architecture: novel functional variants. Hum Mol Genet. 2009;18(6): 1037-1051.

58. Pasternak GW. Molecular biology of opioid analgesia. J Pain Symptom Manage. 2005;29(5 Suppl):S2-S9.

59. Rossi GC, Leventhal L, Pan YX, Cole J, Su W, Bodnar RJ, et al. Antisense mapping of MOR-1 in rats: distinguishing between morphine and morphine-6beta-glucuronide antinociception. J Pharmacol Exp Ther. 1997;281(1):109-114.

60. Schuller AG, King MA, Zhang J, Bolan E, Pan YX, Morgan DJ, et al. Retention of heroin and morphine- 6 beta-glucuronide analgesia in a new line of mice lacking exon 1 of MOR-1. Nature Neuroscience. 1999;2(2):151-156.

61. Pasternak GW. Insights into mu opioid pharmacology the role of mu opioid receptor subtypes. Life Sci. 2001;68(19-20):2213-2219.

62. Zhang Y, Pan YX, Kolesnikov Y, Pasternak GW. Immunohistochemical labeling of the mu opioid receptor carboxy terminal splice variant mMOR-1B4 in the mouse central nervous system. Brain Res 2006;1099(1):33-43.

63. Pan YX. Diversity and complexity of the mu opioid receptor gene: alternative pre-mRNA splicing and promoters. DNA Cell Biol. 2005;24(11):736-750.

64. Pan L, Xu J, Yu R, Xu MM, Pan YX, Pasternak GW. Identification and characterization of six new alternatively spliced variants of the human mu opioid receptor gene, Oprm. Neuroscience. 2005;133(1):209-220.

65. Fricchione G, Zhu W, Cadet P, Mantione KJ, Bromfield E, Madsen J, et al. Identification of endogenous morphine and a mu3-like opiate alkaloid receptor in human brain tissue taken from a patient with intractable complex partial epilepsy. Med Sci Monit. 2008;14(6):CS45-CS49.

66. Gaveriaux-Ruff C, Peluso J, Befort K, Simonin F, Zilliox C, Kieffer BL. Detection of opioid receptor mRNA by RT-PCR reveals alternative splicing for the delta- and kappa-opioid receptors. Brain Res Mol Brain Res. 1997;48(2):298-304.

67. Matthes HW, Maldonado R, Simonin F, Valverde O, Slowe S, Kitchen I, et al. Loss of morphine-induced analgesia, reward effect and withdrawal symptoms in mice lacking the mu-opioid-receptor gene. Nature. 1996;383(6603):819-823.

68. Raynor K, Kong H, Chen Y, Yasuda K, Yu L, Bell GI, et al. Pharmacological characterization of the cloned kappa-, delta-, and mu-opioid receptors. Mol Pharmacol. 1994;45(2):330-334.
69. Satoh M, Minami M. Molecular pharmacology of the opioid receptors. Pharmacol Ther. 1995;68(3):343-364.

70. Khotib J, Narita M, Suzuki M, Yajima Y, Suzuki T. Functional interaction among opioid receptor types: up-regulation of muand delta-opioid receptor functions after repeated stimulation of kappa-opioid receptors. Neuropharmacology. 2004;46(4):531-540.

71. Rozenfeld R, bul-Husn NS, Gomez I, Devi LA. An emerging role for the delta opioid receptor in the regulation of mu opioid receptor function. Scientific WorldJournal. 2007;7:64-73.

72. Park PS, Palczewski K. Diversifying the repertoire of G proteincoupled receptors through oligomerization. Proc Natl Acad Sci USA. 2005;102(25):8793-8794.

73. Gomes I, Jordan BA, Gupta A, Trapaidze N, Nagy V, Devi LA. Heterodimerization of $\mathrm{mu}$ and delta opioid receptors: A role in opiate synergy. J Neurosci. 2000;20(22):RC110.

74. Zhu Y, King MA, Schuller AG, Nitsche JF, Reidl M, Elde RP, et al. Retention of supraspinal delta-like analgesia and loss of morphine tolerance in delta opioid receptor knockout mice. Neuron. 1999;24(1):243-252.

75. Jordan BA, Devi LA. G-protein-coupled receptor heterodimerization modulates receptor function. Nature. 1999;399(6737):697-700.

76. George SR, Fan T, Xie Z, Tse R, Tam V, Varghese G, et al. Oligomerization of mu- and delta-opioid receptors. Generation of novel functional properties. J Biol Chem. 2000;275(34):26128-26135.

77. Waldhoer M, Fong J, Jones RM, Lunzer MM, Sharma SK, Kostenis E, et al. A heterodimer-selective agonist shows in vivo relevance of $\mathrm{G}$ protein-coupled receptor dimers. Proc Natl Acad Sci U S A. 2005;102(25):9050-9055.

78. Davies AN, Dickman A, Reid C, Stevens AM, Zeppetella G. The management of cancer-related breakthrough pain: recommendations of a task group of the Science Committee of the Association for Palliative Medicine of Great Britain and Ireland. Eur J Pain. 2009;13(4):331-338.

79. Portenoy RK, Payne D, Jacobsen P. Breakthrough pain: characteristics and impact in patients with cancer pain. Pain. 1999;81(1-2):129-134.

80. Caraceni A, Martini C, Zecca E, Portenoy RK, Ashby MA, Hawson $\mathrm{G}$, et al. Breakthrough pain characteristics and syndromes in patients with cancer pain. An international survey. Palliat Med. 2004;18(3):177-183.

81. Zeppetella G, O’Doherty CA, Collins S. Prevalence and characteristics of breakthrough pain in cancer patients admitted to a hospice. J Pain Symptom Manage. 2000;20(2):87-92.

82. Zeppetella G. Impact and management of breakthrough pain in cancer. Curr Opin Support Palliat Care. 2009;3(1):1-6.

83. Twycross RG, Wilcock A, Charlesworth S, Dickman A. Palliative Care Formulary. 2nd ed. London: Radcliffe Medical Press; 2002.

84. Mercadante S, Radbruch L, Caraceni A, Cherny N, Kaasa S, Nauck F, et al. Episodic (breakthrough) pain: consensus conference of an expert working group of the European Association for Palliative Care. Cancer. 2002;94(3):832-839.

85. Hao J, Heng PW. Buccal delivery systems. Drug Dev Ind Pharm. 2003;29(8):821-832.

86. Zhang H, Zhang J, Streisand JB. Oral mucosal drug delivery: clinical pharmacokinetics and therapeutic applications. Clin Pharmacokinet. 2002;41(9):661-680.

87. Stevens RA, Ghazi SM. Routes of opioid analgesic therapy in the management of cancer pain. Cancer Control. 2000;7(2):132-141.

88. Electronic Medicines Compendium, Cephalon. Actiq: Summary of product characteristics. Electronic Medicines Compendium 2008 February 11 [cited 2009 Jun 13]; Available from: URL: http://emc. medicines.org.uk/medicine/11145/SPC/Actiq/

89. Mystakidou K, Katsouda E, Parpa E, Vlahos L, Tsiatas ML. Oral transmucosal fentanyl citrate: overview of pharmacological and clinical characteristics. Drug Deliv. 2006;13(4):269-76.

90. Streisand JB, Varvel JR, Stanski DR, Le ML, Ashburn MA, Hague BI, et al. Absorption and bioavailability of oral transmucosal fentanyl citrate. Anesthesiology. 1991;75(2):223-229. 
91. Streisand JB, Busch MA, Egan TD, Smith BG, Gay M, Pace NL. Dose proportionality and pharmacokinetics of oral transmucosal fentanyl citrate. Anesthesiology. 1998;88(2):305-309.

92. Farrar JT, Cleary J, Rauck R, Busch M, Nordbrock E. Oral transmucosal fentanyl citrate: randomized, double-blinded, placebo-controlled trial for treatment of breakthrough pain in cancer patients. $J$ Natl Cancer Inst. 1998;90(8):611-616.

93. Portenoy RK, Payne R, Coluzzi P, Raschko JW, Lyss A, Busch MA, et al. Oral transmucosal fentanyl citrate (OTFC) for the treatment of breakthrough pain in cancer patients: a controlled dose titration study. Pain. 1999;79(2-3):303-312.

94. Coluzzi PH, Schwartzberg L, Conroy JD, Charapata S, Gay M, Busch MA, et al. Breakthrough cancer pain: a randomized trial comparing oral transmucosal fentanyl citrate (OTFC) and morphine sulfate immediate release (MSIR). Pain. 2001;91(1-2):123-130.

95. Christie JM, Simmonds M, Patt R, Coluzzi P, Busch MA, Nordbrock E, et al. Dose-titration, multicenter study of oral transmucosal fentanyl citrate for the treatment of breakthrough pain in cancer patients using transdermal fentanyl for persistent pain. J Clin Oncol. 1998;16(10):3238-3245.

96. Hanks GW, Nugent M, Higgs CM, Busch MA. Oral transmucosal fentanyl citrate in the management of breakthrough pain in cancer: an open, multicentre, dose-titration and long-term use study. Palliat Med. 2004;18(8):698-704.

97. Davies AN, Vriens J. Oral transmucosal fentanyl citrate and xerostomia. J Pain Symptom Manage. 2005;30(6):496-497.

98. Darwish M, Kirby M, Robertson P Jr, Tracewell W, Jiang JG. Absolute and relative bioavailability of fentanyl buccal tablet and oral transmucosal fentanyl citrate. J Clin Pharmacol. 2007;47(3):343-350.

99. Slatkin NE, Xie F, Messina J, Segal TJ. Fentanyl buccal tablet for relief of breakthrough pain in opioid-tolerant patients with cancer-related chronic pain. J Support Oncol. 2007;5(7):327-334.

100. Darwish M, Kirby M, Robertson P, Tracewell W, Jiang JG. Absorption of fentanyl from fentanyl buccal tablet in cancer patients with or without oral mucositis: a pilot study. Clin Drug Investig. 2007;27(9):605-611.

101. Lennernas B, Hedner T, Holmberg M, Bredenberg S, Nystrom C, Lennernas $\mathrm{H}$. Pharmacokinetics and tolerability of different doses of fentanyl following sublingual administration of a rapidly dissolving tablet to cancer patients: a new approach to treatment of incident pain. Br J Clin Pharmacol. 2005;59(2):249-253.

102. Zeppetella G. Nebulized and intranasal fentanyl in the management of cancer-related breakthrough pain. Palliat Med. 2000;14(1):57-58

103. Zeppetella G. An assessment of the safety, efficacy, and acceptability of intranasal fentanyl citrate in the management of cancer-related breakthrough pain: a pilot study. J Pain Symptom Manage. 2000;20(4):253-258.

104. Good P, Jackson K, Brumley D, Ashby M. Intranasal sufentanil for cancer-associated breakthrough pain. Palliat Med. 2009;23(1):54-58.

105. Gardner-Nix J. Oral transmucosal fentanyl and sufentanil for incident pain. J Pain Symptom Manage. 2001;22(2):627-630.

106. Kurz A, Sessler DI. Opioid-induced bowel dysfunction: pathophysiology and potential new therapies. Drugs. 2003;63(7):649-671.

107. McMillan SC, Williams FA. Validity and reliability of the Constipation Assessment Scale. Cancer Nurs. 1989;12(3):183-188.

108. Sykes NP. The pathogenesis of constipation. J Support Oncol. 2006;4(5):213-218.

109. Droney J, Ross J, Gretton S, Welsh K, Sato H, Riley J. Constipation in cancer patients on morphine. Support Care Cancer. 2008;16(5):453-459.

110. Cherny N, Ripamonti C, Pereira J, Davis C, Fallon M, McQuay H, et al. Strategies to manage the adverse effects of oral morphine: an evidence-based report. J Clin Oncol. 2001;19(9):2542-2554.

111. Manara L, Bianchetti A. The central and peripheral influences of opioids on gastrointestinal propulsion. Annu Rev Pharmacol Toxicol. 1985;25:249-273.
112. Waterman SA, Costa M, Tonini M. Modulation of peristalsis in the guinea-pig isolated small intestine by exogenous and endogenous opioids. Br J Pharmacol. 1992;106(4):1004-1010.

113. Stewart JJ, Weisbrodt NW, Burks TF. Central and peripheral actions of morphine on intestinal transit. J Pharmacol Exp Ther. 1978;205(3):547-555.

114. Basilisco G, Bozzani A, Camboni G, Recchia M, Quatrini M, Conte D, et al. Effect of loperamide and naloxone on mouth-to-caecum transit time evaluated by lactulose hydrogen breath test. Gut. 1985;26(7): 700-703.

115. Sternini C, Patierno S, Selmer IS, Kirchgessner A. The opioid system in the gastrointestinal tract. Neurogastroenterol Motil. 2004; 16 Suppl 2:3-16.

116. Bianchi G, Ferretti P, Recchia M, Rocchetti M, Tavani A, Manara L. Morphine tissue levels and reduction of gastrointestinal transit in rats. Correlation supports primary action site in the gut. Gastroenterology. 1983;85(4):852-858.

117. Roy S, Liu HC, Loh HH. mu-Opioid receptor-knockout mice: the role of mu-opioid receptor in gastrointestinal transit. Brain Res Mol Brain Res. 1998;56(1-2):281-283.

118. Tatsumi H, Costa M, Schimerlik M, North RA. Potassium conductance increased by noradrenaline, opioids, somatostatin, and G-proteins: whole-cell recording from guinea pig submucous neurons. J Neurosci. 1990;10(5):1675-1682.

119. Surprenant A, Shen KZ, North RA, Tatsumi H. Inhibition of calcium currents by noradrenaline, somatostatin and opioids in guinea-pig submucosal neurones. J Physiol. 1990;431:585-608.

120. Hicks GA, Haven-Hudkins DL, Camilleri M. Opiates in the control of gastrointestinal tract function: current knowledge and new avenues for research. Neurogastroenterol Motil. 2004;16 Suppl 2: 67-70.

121. De LA, Coupar IM. Insights into opioid action in the intestinal tract. Pharmacol Ther. 1996;69(2):103-115.

122. Miles C, Fellowes D, Goodman M, Wilkinson S. Laxatives for the management of constipation in palliative care patients. Cochrane Database Syst Rev. 2006;(4):CD003448.

123. Fishman J, Roffwarg H, Hellman L. Disposition of naloxone-7,8,3H in normal and narcotic-dependent men. $J$ Pharmacol Exp Ther. 1973;187(3):575-580.

124. Moss J, Rosow CE. Development of peripheral opioid antagonists' new insights into opioid effects. Mayo Clin Proc. 2008;83(10):1116-1130.

125. Culpepper-Morgan JA, Inturrisi CE, Portenoy RK, Foley K, Houde RW, Marsh F, et al. Treatment of opioid-induced constipation with oral naloxone: a pilot study. Clin Pharmacol Ther. 1992;52(1):90-95.

126. Latasch L, Zimmermann M, Eberhardt B, Jurna I. [Treament of morphine-induced constipation with oral naloxone]. Anaesthesist. 1997;46(3):191-194.

127. Sykes NP. An investigation of the ability of oral naloxone to correct opioid-related constipation in patients with advanced cancer. Palliat Med. 1996;10(2):135-144.

128. Meissner W, Schmidt U, Hartmann M, Kath R, Reinhart K. Oral naloxone reverses opioid-associated constipation. Pain. 2000;84(1):105-109.

129. Liu M, Wittbrodt E. Low-dose oral naloxone reverses opioid-induced constipation and analgesia. J Pain Symptom Manage. 2002;23(1):48-53.

130. Meissner W, Leyendecker P, Mueller-Lissner S, Nadstawek J, Hopp M, Ruckes C, et al. A randomised controlled trial with prolonged-release oral oxycodone and naloxone to prevent and reverse opioid-induced constipation. Eur J Pain. 2009;13(1):56-64.

131. Lowenstein O, Leyendecker P, Hopp M, Schutter U, Rogers PD, Uhl R, et al. Combined prolonged-release oxycodone and naloxone improves bowel function in patients receiving opioids for moderate-to-severe non-malignant chronic pain: a randomised controlled trial. Expert Opin Pharmacother. 2009;10(4):531-543. 
132. Simpson K, Leyendecker P, Hopp M, Muller-Lissner S, Lowenstein O, De AJ, et al. Fixed-ratio combination oxycodone/naloxone compared with oxycodone alone for the relief of opioid-induced constipation in moderate-to-severe noncancer pain. Curr Med Res Opin. 2008;24(12):3503-3512.

133. Brown DR, Goldberg LI. The use of quaternary narcotic antagonists in opiate research. Neuropharmacology. 1985;24(3):181-191.

134. Holzer P. Opioids and opioid receptors in the enteric nervous system: from a problem in opioid analgesia to a possible new prokinetic therapy in humans. Neurosci Lett. 2004 6;361(1-3):192-195.

135. Yuan CS, Foss JF, O’Connor M, Toledano A, Roizen MF, Moss J. Methylnaltrexone prevents morphine-induced delay in oral-cecal transit time without affecting analgesia: a double-blind randomized placebo-controlled trial. Clin Pharmacol Ther. 1996;59(4): 469-475.

136. Yuan CS, Foss JF, O’Connor M, Osinski J, Karrison T, Moss J, et al. Methylnaltrexone for reversal of constipation due to chronic methadone use: a randomized controlled trial. JAMA. 2000 19; 283(3):367-372.

137. Thomas J, Karver S, Cooney GA, Chamberlain BH, Watt CK, Slatkin NE, et al. Methylnaltrexone for opioid-induced constipation in advanced illness. N Engl J Med. 2008;358(22):2332-2343.

138. Slatkin N, Thomas J, Lipman AG, Wilson G, Boatwright ML, Wellman C, et al. Methylnaltrexone for treatment of opioid-induced constipation in advanced illness patients. J Support Oncol. 2009;7(1):39-46.

139. Wyeth Pharmaceuticals. Methylnaltrexone Summary of product Characteristics. Electronic Medicines Compendium 2008 [cited 2009 Jun 5]; Available from: URL: http://emc.medicines.org.uk/ medicine/20982/SPC/Relistor/

140. Yuan CS, Foss JF, Osinski J, Toledano A, Roizen MF, Moss J. The safety and efficacy of oral methylnaltrexone in preventing morphineinduced delay in oral-cecal transit time. Clin Pharmacol Ther. 1997;61(4):467-475.

141. Yuan CS, Foss JF, O’Connor M, Karrison T, Osinski J, Roizen MF, et al. Effects of enteric-coated methylnaltrexone in preventing opioid-induced delay in oral-cecal transit time. Clin Pharmacol Ther. 2000;67(4):398-404

142. Zimmerman DM, Gidda JS, Cantrell BE, Schoepp DD, Johnson BG, Leander JD. Discovery of a potent, peripherally selective trans-3,4-dimethyl-4-(3-hydroxyphenyl)piperidine opioid ++ antagonist for the treatment of gastrointestinal motility disorders. J Med Chem. 1994 22;37(15):2262-2265.

143. Foss JF, Fisher DM, Schmith VD. Pharmacokinetics of alvimopan and its metabolite in healthy volunteers and patients in postoperative ileus trials. Clin Pharmacol Ther. 2008;83(5): 770-776

144. Camilleri M. Alvimopan, a selective peripherally acting mu-opioid antagonist. Neurogastroenterol Motil. 2005;17(2):157-165.

145. Liu SS, Hodgson PS, Carpenter RL, Fricke JR Jr. ADL 8-2698, a trans-3,4-dimethyl-4-(3-hydroxyphenyl) piperidine, prevents gastrointestinal effects of intravenous morphine without affecting analgesia. Clin Pharmacol Ther. 2001;69(1):66-71.

146. Taguchi A, Sharma N, Saleem RM, Sessler DI, Carpenter RL, Seyedsadr M, et al. Selective postoperative inhibition of gastrointestinal opioid receptors. $N$ Engl J Med. 2001;345(13): 935-940

147. Herzog TJ, Coleman RL, Guerrieri JP Jr, Gabriel K, Du W, Techner L, et al. A double-blind, randomized, placebo-controlled phase III study of the safety of alvimopan in patients who undergo simple total abdominal hysterectomy. Am J Obstet Gynecol. 2006;195(2):445-453.

148. Delaney CP, Weese JL, Hyman NH, Bauer J, Techner L, Gabriel K, et al. Phase III trial of alvimopan, a novel, peripherally acting, mu opioid antagonist, for postoperative ileus after major abdominal surgery. Dis Colon Rectum. 2005;48(6):1114-1125.
149. Webster L, Jansen JP, Peppin J, Lasko B, Irving G, Morlion B, et al. Alvimopan, a peripherally acting mu-opioid receptor (PAM-OR) antagonist for the treatment of opioid-induced bowel dysfunction: results from a randomized, double-blind, placebo-controlled, dosefinding study in subjects taking opioids for chronic non-cancer pain. Pain. 2008;137(2):428-440.

150. Paulson DM, Kennedy DT, Donovick RA, Carpenter RL, Cherubini M, Techner L, et al. Alvimopan: an oral, peripherally acting, mu-opioid receptor antagonist for the treatment of opioid-induced bowel dysfunction - a 21-day treatment-randomized clinical trial. J Pain. 2005;6(3):184-192.

151. Moss J, Rosow CE. Development of peripheral opioid antagonists' new insights into opioid effects. Mayo Clin Proc. 2008;83(10):1116-1130

152. Thomas J. Opioid-induced bowel dysfunction. J Pain Symptom Manage. 2008;35(1):103-113.

153. McNicol ED, Boyce D, Schumann R, Carr DB. Mu-opioid antagonists for opioid-induced bowel dysfunction. Cochrane Database Syst Rev. 2008;(2):CD006332.

154. Greenwood-Van MB, Gardner CJ, Little PJ, Hicks GA, Haven-Hudkins DL. Preclinical studies of opioids and opioid antagonists on gastrointestinal function. Neurogastroenterol Motil. 2004;16 Suppl 2:46-53.

155. Kaufman PN, Krevsky B, Malmud LS, Maurer AH, Somers MB, Siegel JA, et al. Role of opiate receptors in the regulation of colonic transit. Gastroenterology. 1988;94(6):1351-1356.

156. Mani AR, Moore KP. New insights into the role of endogenous opioids in the pathogenesis of gastrointestinal and liver disease. Gut. 2009;58(7):893-895.

157. Yuan CS, Foss JF, Moss J. Effects of methylnaltrexone on morphineinduced inhibition of contraction in isolated guinea-pig ileum and human intestine. Eur J Pharmacol. 1995;276(1-2):107-111.

158. Yuan CS, Doshan H, Charney MR, O'Connor M, Karrison T, Maleckar SA, et al. Tolerability, gut effects, and pharmacokinetics of methylnaltrexone following repeated intravenous administration in humans. J Clin Pharmacol. 2005;45(5):538-546.

159. Kreek MJ, Schaefer RA, Hahn EF, Fishman J. Naloxone, a specific opioid antagonist, reverses chronic idiopathic constipation. Lancet. 1983;1(8319):261-262.

160. Beattie DT, Cheruvu M, Mai N, O’Keefe M, Johnson-Rabidoux S, Peterson $\mathrm{C}$, et al. The in vitro pharmacology of the peripherally restricted opioid receptor antagonists, alvimopan, ADL 08-0011 and methylnaltrexone. Naunyn Schmiedebergs Arch Pharmacol. 2007;375(3):205-220.

161. Bohn LM, Raehal KM. Opioid receptor signaling: relevance for gastrointestinal therapy. Curr Opin Pharmacol. 2006;6(6):559-563.

162. Sykes N. Using oral naloxone in management of opioid bowel dysfunction. In: Yuan CS, editor. Handbook of Opioid Bowel Dysfunction. New York: Haworth Medical Press; 2005:175-195.

163. Breivik H, Cherny N, Collett B, De CF, Filbet M, Foubert AJ, et al. Cancer-related pain: a pan-European survey of prevalence, treatment, and patient attitudes. Ann Oncol. 2009;20(8):1420-1433.

164. Tracey I. Neuroimaging of pain mechanisms. Curr Opin Support Palliat Care. 2007;1(2):109-116.

165. Wise RG, Rogers R, Painter D, Bantick S, Ploghaus A, Williams P, et al. Combining fMRI with a pharmacokinetic model to determine which brain areas activated by painful stimulation are specifically modulated by remifentanil. Neuroimage. 2002;16(4):999-1014.

166. Persson K, Hammarlund-Udenaes M, Mortimer O, Rane A. The postoperative pharmacokinetics of codeine. Eur J Clin Pharmacol. 1992;42(6):663-666.

167. Leppert W, Luczak J. The role of tramadol in cancer pain treatment - a review. Support Care Cancer. 2005;13(1):5-17.

168. Buetler TM, Wilder-Smith OH, Wilder-Smith CH, Aebi S, Cerny T, Brenneisen R. Analgesic action of i.v. morphine-6-glucuronide in healthy volunteers. Br J Anaesth. 2000;84(1):97-99. 
169. Gourlay GK, Cherry DA, Cousins MJ. A comparative study of the efficacy and pharmacokinetics of oral methadone and morphine in the treatment of severe pain in patients with cancer. Pain. 1986;25(3):297-312.

170. Hoskin PJ, Hanks GW, Aherne GW, Chapman D, Littleton P, Filshie J. The bioavailability and pharmacokinetics of morphine after intravenous, oral and buccal administration in healthy volunteers. $\mathrm{Br} J$ Clin Pharmacol. 1989;27(4):499-505.

171. McQuay HJ, Carroll D, Faura CC, Gavaghan DJ, Hand CW, Moore RA. Oral morphine in cancer pain: influences on morphine and metabolite concentration. Clin Pharmacol Ther. 1990;48(3): 236-244.

172. Sear JW, Hand CW, Moore RA, McQuay HJ. Studies on morphine disposition: influence of renal failure on the kinetics of morphine and its metabolites. Br J Anaesth. 1989;62(1):28-32.

173. Lalovic B, Kharasch E, Hoffer C, Risler L, Liu-Chen LY, Shen DD. Pharmacokinetics and pharmacodynamics of oral oxycodone in healthy human subjects: role of circulating active metabolites. Clin Pharmacol Ther. 2006;79(5):461-479.

174. Heiskanen T, Olkkola KT, Kalso E. Effects of blocking CYP2D6 on the pharmacokinetics and pharmacodynamics of oxycodone. Clin Pharmacol Ther. 1998;64(6):603-611.

175. Kalso E. How different is oxycodone from morphine? Pain. 2007 5;132(3):227-228.

176. Nielsen CK, Ross FB, Lotfipour S, Saini KS, Edwards SR, Smith MT. Oxycodone and morphine have distinctly different pharmacological profiles: radioligand binding and behavioural studies in two rat models of neuropathic pain. Pain. 2007;132(3):289-300.

177. Poyhia R, Seppala T, Olkkola KT, Kalso E. The pharmacokinetics and metabolism of oxycodone after intramuscular and oral administration to healthy subjects. Br J Clin Pharmacol. 1992;33(6): 617-621.

178. Bruera E, Belzile M, Pituskin E, Fainsinger R, Darke A, Harsanyi Z, et al. Randomized, double-blind, cross-over trial comparing safety and efficacy of oral controlled-release oxycodone with controlled-release morphine in patients with cancer pain. J Clin Oncol. 1998;16(10): 3222-3229.

179. Lauretti GR, Oliveira GM, Pereira NL. Comparison of sustained-release morphine with sustained-release oxycodone in advanced cancer patients. Br J Cancer. 2003;89(11):2027-2030.

180. Kirvela M, Lindgren L, Seppala T, Olkkola KT. The pharmacokinetics of oxycodone in uremic patients undergoing renal transplantation. J Clin Anesth. 1996;8:13-18.

181. Donner B, Zenz M, Tryba M, Strumpf M. Direct conversion from oral morphine to transdermal fentanyl: a multicenter study in patients with cancer pain. Pain. 1996;64(3):527-534.

182. Mather LE. Clinical pharmacokinetics of fentanyl and its newer derivatives. Clin Pharmacokinet. 1983;8(5):422-446.

183. Eap CB, Buclin T, Baumann P. Interindividual variability of the clinical pharmacokinetics of methadone: implications for the treatment of opioid dependence. Clin Pharmacokinet. 2002;41(14):1153-1193.

184. Inturrisi CE, Colburn WA, Kaiko RF, Houde RW, Foley KM. Pharmacokinetics and pharmacodynamics of methadone in patients with chronic pain. Clin Pharmacol Ther. 1987;41(4): 392-401.

185. Ripamonti C, Groff L, Brunelli C, Polastri D, Stavrakis A, De Conno F. Switching from morphine to oral methadone in treating cancer pain: what is the equianalgesic dose ratio? J Clin Oncol. 1998;16(10):3216-3221.

186. Baselt RC, Casarett LJ. Biliary and urinary elimination of methadone and its metabolites in the rat. Biochem Pharmacol. 1972;21(20):2704-2712.

187. Cone EJ, Gorodetzky CW, Yousefnejad D, Buchwald WF, Johnson RE. The metabolism and excretion of buprenorphine in humans. Drug Metab Dispos. 1984;12(5):577-581.
188. Electronic Medicines Compendium, Napp pharmaceuticals limited. Transtec (buprenorphine) transdermal patch. Summary of product characteristics. Electronic Medicines Compendium 2007. Available from: URL: http://emc.medicines.org.uk/document. aspx?documentId=8864.

189. Sittl R, Likar R, Nautrup BP. Equipotent doses of transdermal fentanyl and transdermal buprenorphine in patients with cancer and noncancer pain: results of a retrospective cohort study. Clin Ther. 2005;27(2):225-237.

190. Sittl R. Transdermal buprenorphine in cancer pain and palliative care. Palliat Med. 2006;(20 Suppl 1):s25-s30.

191. Gal TJ. Naloxone reversal of buprenorphine-induced respiratory depression. Clin Pharmacol Ther. 1989;45(1):66-71.

192. Zheng M, McErlane KM, Ong MC. Hydromorphone metabolites: isolation and identification from pooled urine samples of a cancer patient. Xenobiotica. 2002;32(5):427-439.

193. Murray A, Hagen NA. Hydromorphone. J Pain Symptom Manage. 2005;29(5 Suppl):S57-S66.

194. Parab PV, Ritschel WA, Coyle DE, Gregg RV, Denson DD. Pharmacokinetics of hydromorphone after intravenous, peroral and rectal administration to human subjects. Biopharm Drug Dispos. 1988;9(2):187-199.

195. Vallner JJ, Stewart JT, Kotzan JA, Kirsten EB, Honigberg IL. Pharmacokinetics and bioavailability of hydromorphone following intravenous and oral administration to human subjects. J Clin Pharmacol. 1981;21(4):152-156.

196. Sarhill N, Walsh D, Nelson KA. Hydromorphone: pharmacology and clinical applications in cancer patients. Support Care Cancer. 2001;9(2):84-96.

197. Babul N, Darke AC, Hagen N. Hydromorphone metabolite accumulation in renal failure. J Pain Symptom Manage. 1995;10(3):184-186.

198. Kharasch ED, Russell M, Mautz D, Thummel KE, Kunze KL, Bowdle A, et al. The role of cytochrome P450 3A4 in alfentanil clearance. Implications for interindividual variability in disposition and perioperative drug interactions. Anesthesiology. 1997;87(1):36-50.

199. Stanski DR. The clinical pharmacology of alfentanil. Eur J Anaesthesiol Suppl. 1987;1:3-11.

200. Meuldermans W, van Peer A, Hendrick J, et.al. Alfentanil pharmacokinetics and metabolism in humans. Anesthesiology. 1998;69:527-534.

201. Kent AP, Dodson ME, Bower S. The pharmacokinetics and clinical effects of a low dose of alfentanil in elderly patients. Acta Anaesthesiol Belg. 1988;39(1):25-33.

202. Mercadante S, Casuccio A, Fulfaro F, Groff L, Boffi R, Villari P, et al. Switching from morphine to methadone to improve analgesia and tolerability in cancer patients: a prospective study. J Clin Oncol. 2001;19(11):2898-2904.

203. Ross JR, Rutter D, Welsh K, Joel SP, Goller K, Wells AU, et al. Clinical response to morphine in cancer patients and genetic variation in candidate genes. Pharmacogenomics J. 2005;5(5):324-336.

204. Ross JR, Riley J, Taegetmeyer AB, Sato H, Gretton S, du Bois RM, et al. Genetic variation and response to morphine in cancer patients: catechol-o-methyltransferase and multidrug resistance-1 gene polymorphisms are associated with central side effects. Cancer. 2008;112(6):1390-1403.

205. Rakvag TT, Klepstad P, Baar C, Kvam TM, Dale O, Kaasa S, et al. The Val158Met polymorphism of the human catechol-O-methyltransferase (COMT) gene may influence morphine requirements in cancer pain patients. Pain. 2005;116(1-2):73-78.

206. Rakvag TT, Ross JR, Sato H, Skorpen F, Kaasa S, Klepstad P. Genetic variation in the catechol-O-methyltransferase (COMT) gene and morphine requirements in cancer patients with pain. Mol Pain. 2008;4:64.

207. Lefkowitz RJ, Shenoy SK. Transduction of receptor signals by beta-arrestins. Science. 2005;308(5721):512-517. 
208. Shenoy SK, McDonald PH, Kohout TA, Lefkowitz RJ. Regulation of receptor fate by ubiquitination of activated beta 2-adrenergic receptor and beta-arrestin. Science. 2001;294(5545):1307-1313.

209. Holthe M, Rakvag TN, Klepstad P, Idle JR, Kaasa S, Krokan HE, et al. Sequence variations in the UDP-glucuronosyltransferase 2B7 (UGT2B7) gene: identification of 10 novel single nucleotide polymorphisms (SNPs) and analysis of their relevance to morphine glucuronidation in cancer patients. Pharmacogenomics J. 2003;3(1):17-26.
210. Holthe M, Klepstad P, Zahlsen K, Borchgrevink PC, Hagen L, Dale O, et al. Morphine glucuronide-to-morphine plasma ratios are unaffected by the UGT2B 7 H268Y and UGT1A1*28 polymorphisms in cancer patients on chronic morphine therapy. Eur J Clin Pharmacol. 2002;58(5):353-356.

\section{Publish your work in this journal}

The Journal of Pain Research is an international, peer-reviewed, open access, online journal that welcomes laboratory and clinical findings in the fields of pain research and the prevention and managemen of pain. Original research, reviews, symposium reports, hypothesis formation and commentaries are all considered for publication.

\section{Dovepress}

The manuscript management system is completely online and includes a very quick and fair peer-review system, which is all easy to use. Visit http://www.dovepress.com/testimonials.php to read real quotes from published authors. 